Article

\title{
Land Subsidence Susceptibility Mapping in Jakarta Using Functional and Meta-Ensemble Machine Learning Algorithm Based on Time-Series InSAR Data
}

\author{
Wahyu Luqmanul Hakim $\mathbb{D}^{D}$, Arief Rizqiyanto Achmad $\mathbb{D}^{\circ}$ and Chang-Wook Lee * $\mathbb{D}$ \\ Division of Science Education, Kangwon National University, Gangwon-do, Chuncheon-si 24341, Korea; \\ wahyulhakim@kangwon.ac.kr (W.L.H.); ariefrizqiyanto@kangwon.ac.kr (A.R.A.) \\ * Correspondence: cwlee@kangwon.ac.kr
}

Received: 10 September 2020; Accepted: 3 November 2020; Published: 4 November 2020

\begin{abstract}
Areas at risk of land subsidence in Jakarta can be identified using a land subsidence susceptibility map. This study evaluates the quality of a susceptibility map made using functional (logistic regression and multilayer perceptron) and meta-ensemble (AdaBoost and LogitBoost) machine learning algorithms based on a land subsidence inventory map generated using the Sentinel-1 synthetic aperture radar (SAR) dataset from 2017 to 2020. The land subsidence locations were assessed using the time-series interferometry synthetic aperture radar (InSAR) method based on the Stanford Method for Persistent Scatterers (StaMPS) algorithm. The mean vertical deformation maps from ascending and descending tracks were compared and showed a good correlation between displacement patterns. Persistent scatterer points with mean vertical deformation value were randomly divided into two datasets: $50 \%$ for training the susceptibility model and 50\% for validating the model in terms of accuracy and reliability. Additionally, 14 land subsidence conditioning factors correlated with subsidence occurrence were used to generate land subsidence susceptibility maps from the four algorithms. The receiver operating characteristic (ROC) curve analysis showed that the AdaBoost algorithm has higher subsidence susceptibility prediction accuracy $(81.1 \%)$ than the multilayer perceptron $(80 \%)$, logistic regression $(79.4 \%)$, and LogitBoost $(79.1 \%)$ algorithms. The land subsidence susceptibility map can be used to mitigate disasters caused by land subsidence in Jakarta, and our method can be applied to other study areas.
\end{abstract}

Keywords: Jakarta; land subsidence susceptibility mapping; time-series InSAR; StaMPS processing; machine learning

\section{Introduction}

Several cities in Indonesia suffer from degradation at the ground level of buildings, known as land subsidence [1,2]. In Jakarta, this process has had a severe impact on urban infrastructure, leading to cracks in buildings, roads and damage to drainage systems [3]. These conditions are problematic because land subsidence may expand coastal flood areas due to sea-level rise [4]. Heavy monsoon rainfall [5] has caused frequent river flooding; if this occurs again, Jakarta could be submerged entirely underwater $[1,4]$.

Recent studies of land subsidence in Jakarta have used various geodetic measurement methods, such as leveling surveys [3] and a global positioning system (GPS) surveys [6,7]. These studies indicated that excessive groundwater extraction is the leading cause of land subsidence and compaction to the vulnerable aquifer system [8]. This compaction may be exacerbated by natural consolidation since Jakarta's landform mostly comprises young alluvial soils that cannot support the weight of 
human-made structures $[9,10]$. Therefore, it is essential to monitor land subsidence in Jakarta to predict further possible occurrences and mitigate damage [11,12].

Over the last decade, land subsidence susceptibility maps have been generated using geological, geomorphological, topographical, and hydrological data; these are considered the main factors influencing land subsidence $[11,13,14]$. Various methods are used to generate land subsidence susceptibility maps, including frequency ratios (FR) [12,15], weight of evidence (WOE) [16,17], logistic regression (LR) [18], evidential belief functions [11], analytical hierarchy processes (AHP) [19], support vector machines (SVM) [14,20], decision trees [21,22], fuzzy logic [12,23], adaptive neuro-fuzzy inference systems (ANFIS) [24,25], and artificial neural networks (ANN) [26,27]. In general, using a single modeling method leads to lower predictive accuracy than an ensemble method that uses a combination of models and machine learning algorithms $[13,28]$. Machine learning algorithms have the advantage of finding unpredictable relationships in datasets at multiple scales and have, thus, been recommended to obtain accurate land subsidence susceptibility maps [22].

Another challenge in generating land subsidence susceptibility maps is the low availability of land subsidence inventory maps. In this study, a land subsidence inventory map was generated via time-series interferometry synthetic aperture radar (InSAR) analysis. This technique can be applied to measure the displacement of the earth's surface with an accuracy of up to millimeters per year by improving the selection of coherent pixels and reducing atmospheric noise [29-33]. It has been widely used to monitor land subsidence and generate land subsidence maps, for example, in large cities in Mexico [33,34], Kurdistan, and Iran [35], in Yuncheng Basin, China [36], and in coastal cities and areas such as Venice, Italy [37], New Orleans, United States [38], and Shanghai, China [39]. The InSAR algorithm has been successfully applied to earthquakes [40], volcanic activities [41,42], crustal deformation [31], landslides [43], manmade deformations [44], excessive groundwater extraction [3], mining activities [45], and natural consolidation of young alluvial soil [9].

The recent studies of monitoring land subsidence in Jakarta using interferometry synthetic aperture radar (InSAR) techniques was conducted using the Small Baseline Subset (SBAS) algorithm from 2007 to 2009 [1] and using Geodesy and Earth Observing Systems-Persistent Scatterer Interferometry (GEOS-PSI) algorithm from 2007 to 2010 [46]. Both studies utilized Advanced Land Observing Satellite (ALOS) phased array type-L synthetic aperture radar (PALSAR) data to produce a land subsidence map, and both compared their results with GPS survey data. However, Jakarta's land subsidence map requires updating as it has remained unchanged for the past 10 years, and research on land subsidence susceptibility maps was not found in Jakarta.

Therefore, this study's objective was to generate the updated land subsidence map in Jakarta using the Stanford Method for Persistent Scatterers (StaMPS) with the Sentinel-1 synthetic aperture radar (SAR) dataset from March 2017 to May 2020 in ascending track and March 2017 to April 2020 in a descending track. The mean vertical deformation maps in ascending and descending tracks were compared to validate Jakarta's land subsidence location. After that, the land subsidence map obtained with this method was used as an inventory map to generate a land subsidence susceptibility map in Jakarta that predicted the areas at risk of land subsidence in the future. Two meta-ensemble machine learning algorithms (adaptive boosting (AdaBoost) and Logit Boost), and two functional machine learning algorithms (logistic regression and multilayer perceptron) were used. The result of the land subsidence susceptibility map produced by these algorithms was evaluated to compare all models' accuracy and reliability using receiver operating characteristic (ROC) curve analysis.

\section{Study Area}

Jakarta is Indonesia's capital city (Figure 1a), located at $6^{\circ} 17^{\prime}$ south (S) and $106^{\circ} 82^{\prime}$ east (E), on the northern coast of western Java. It is considered a lowland area, with an average altitude of $\pm 7 \mathrm{~m}$ above sea level [3,47]. In 2019, its population was 10.5 million, with a population growth rate of about $1.19 \%$ per year. The population density was 15,900 people per $\mathrm{km}^{2}$, within a total land area of $662.33 \mathrm{~km}^{2}$ [47]. Historically, the population of Jakarta gradually migrated to the other districts 
and municipalities that are part of the Jakarta Metropolitan Region (JMR), which covers a total area of $5897 \mathrm{~km}^{2}$ and includes Bogor, Depok, Tangerang, and Bekasi [48] (Figure 1b). This migration to Jakarta's outskirts led to increased urban development that could cause land subsidence in these areas [3]. Our study area covers the JMR; however, for simplicity, we refer to it as Jakarta. The three administrative areas were chosen as study area due to land subsidence reported on those areas from the recent study using GPS surveys, leveling surveys, and InSAR techniques. Training and testing data in Figure $1 \mathrm{~b}$ used in this study to generate a land subsidence susceptibility map were assessed from the land subsidence inventory map.

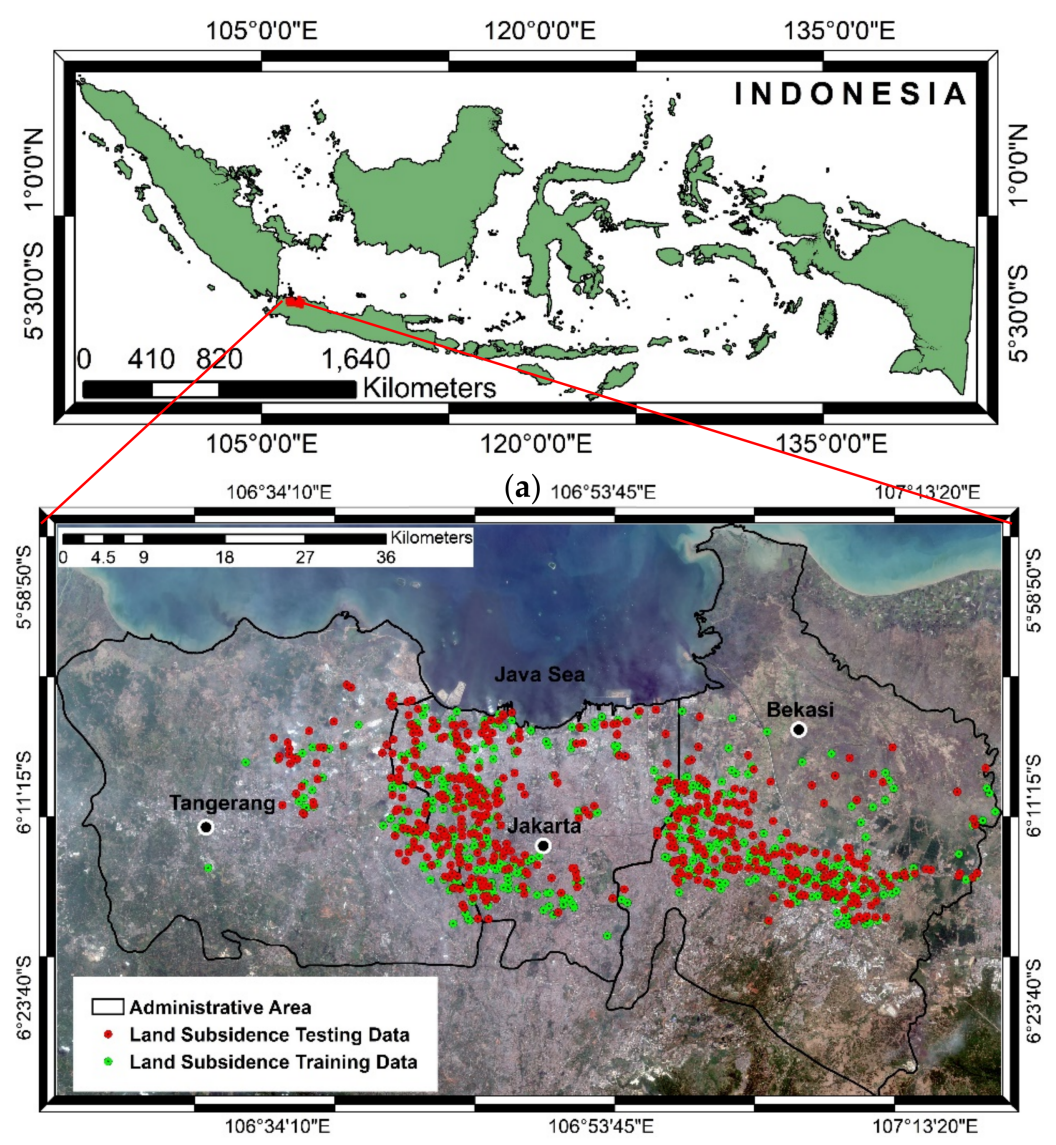

(b)

Figure 1. (a) Study area location in Indonesia and (b) training and testing data sets from land subsidence location within Jakarta Metropolitan Region (JMR) depicted from Sentinel-2 satellite imagery taken on 28 August 2020, divided into three administrative areas: Jakarta, Tangerang, and Bekasi.

The geological and geomorphological area in Jakarta lithologically was dominated by alluvium landform (50.20\%) and alluvium fans (19.66\%), followed by Serpong form (7.03\%) that dominated by fragmented pumice sandstones, some limestone, and andesite. A volcanic pyroclastic flow formed tuff Banten (6.77\%) and upper Banten tuff (4.88\%), Sandstone unit (4.05\%), swamp deposit $(1.75 \%)$, Cihoe form $(1.61 \%)$, beach ridge deposit $(1.53 \%)$, and old alluvium $(0.74 \%)$. Subang form $(0.64 \%)$ was dominated by layered claystone lithology with limestone and marl found locally, marine deposit $(0.52 \%)$, and young volcanic rocks $(0.22 \%)$; Bojongmanik form $(0.22 \%)$ was dominated by alternating sandstones and claystone inserted by limestones and coastal deposit $(0.13 \%)$; Parigi form $(0.05 \%)$ was dominated by medium limestone, lake $(0.01 \%)$, and sandstone tuff $(0.01 \%)$. The domination of alluvium landform has a risk of land subsidence due to the compaction of natural consolidation worsened by a human-made structure [3,9] covering the Jakarta area's land use. Land use in Jakarta was dominated by settlement area with $45.72 \%$ and followed by $39.79 \%$ of rice field, $5.94 \%$ of dryland 
agriculture, $4.75 \%$ of fish pond, $1.98 \%$ of shrub-mixed dryland farms, $0.84 \%$ of airport, $0.51 \%$ of swamp, $0.35 \%$ of estate crop plantation, $0.09 \%$ of barren land, $0.03 \%$ of secondary mangrove forest, and $0.004 \%$ of swamp shrub.

Research on land subsidence in Jakarta has been conducted since 1982 using leveling surveys. There were two main monitoring periods: (1) 1982-1991 and (2) 1991-1997. Land subsidence was found in the period 1982-1991 in three regions with the highest accumulated subsidence value compared to other regions, namely, two regions in the northwestern part (Cengkareng and Kalideres districts) and the third in the northeastern part of Jakarta (Kemayoran-Sunter district); accumulated subsidence was found in Kalideres district with up to $68.5 \mathrm{~cm}$ between 1982 and 1991 with an annual rate of subsidence around $8 \mathrm{~cm} /$ year. Accumulated land subsidence was found in the Cengkareng district, with up to $60 \mathrm{~cm}$ between 1982 and 1991, with an annual subsidence rate of around $7 \mathrm{~cm} /$ year. Accumulated land subsidence was found in the Kemayoran-Sunter district, with up to $70 \mathrm{~cm}$ with an annual subsidence rate of around $6 \mathrm{~cm} /$ year. The second period of monitoring land subsidence using a leveling survey between 1991 and 1997 highlighted one region with the highest accumulated subsidence value than other regions in the Kalideres district, with up to $154.1 \mathrm{~cm}$ with an annual subsidence rate of around $23 \mathrm{~cm} /$ year [7].

Following this research, land subsidence in Jakarta was monitored using GPS surveys from 1997 to 2005, and two regions affected by land subsidence were reported in two stations: (1) Kwitang district and (2) Pantai Mutiara district. The accumulated land subsidence was found in the Kwitang district, with up to $48 \mathrm{~cm}$ with an annual rate of subsidence rate of $5 \mathrm{~cm} / \mathrm{year}$; accumulated land subsidence in Pantai Mutiara district was around $50 \mathrm{~cm}$ with an annual rate of subsidence around $4.6 \mathrm{~cm} /$ year. [6]. Land subsidence in Jakarta measured using leveling and GPS surveys positively correlated with excessive groundwater extraction and sea-level rise [6,7,49].

Land subsidence was also reported using InSAR techniques based on ALOS PALSAR satellite data in 2007-2009 using the SBAS method, with land subsidence found in Pluit district with an annual subsidence rate of $21.6 \mathrm{~cm} /$ year. Land subsidence was found in Cengkareng district with an annual subsidence rate around $21.8 \mathrm{~cm} /$ year, in Bekasi district with an annual rate of subsidence of around $10.6 \mathrm{~cm} /$ year, and in Karawang district with an annual rate of around $16.4 \mathrm{~cm} /$ year [1]. Research was also conducted with ALOS PALSAR satellite data within the period 2007-2010 using the GEOS-PSI method, finding land subsidence in the coastal area and lowland area in northwestern Jakarta within Penjaringan and Cengkareng districts with an annual subsidence rate of up to $26 \mathrm{~cm} /$ year, with accumulated subsidence rates of up to $86.5 \mathrm{~cm}$ between 2007 and 2010. Land subsidence was observed in the Bekasi district with an annual subsidence rate of up to $11.5 \mathrm{~cm} /$ year [46].

\section{Material and Methods}

\subsection{SAR Datasets}

A land subsidence inventory map for generating the land subsidence susceptibility map in Jakarta was generated using Sentinel-1 SAR C-band data $(5.5 \mathrm{~cm}$ wavelength) provided by the European Space Agency (ESA). The SAR data were acquired from March 2017 to May 2020 (91 datasets in the ascending track with path number 98 and frame number 1160, with vertical-vertical (VV) polarization) and in the period of March 2017 to April 2020 (89 datasets in the descending track with path number 47 and frame number 614, with vertical-vertical (VV) polarization). The ascending and descending datasets are listed in Tables 1 and 2, and the reference dates with zero delta day and zero perpendicular baselines from the ascending track are shown on 15 October 2018, whereas those from the descending track are shown on 16 November 2018; both reference dates are shown in bold text in table number 45 . A perpendicular baseline graph (generated from Tables 1 and 2 and shown in Figure 2) was used to visualize the temporal baseline from the reference date. 
Table 1. Acquisition dates (format ddmmyyyy) of the Sentinel-1 synthetic aperture radar (SAR) datasets in ascending track. Delta days $=$ number of days between each acquisition date. $\mathrm{B} \perp=$ perpendicular baseline. The reference dates in ascending tracks are shown in bold text.

\begin{tabular}{|c|c|c|c|c|c|c|c|c|c|c|c|}
\hline No. & $\begin{array}{c}\text { Acquisition Date } \\
\text { (ddmmyyyy) }\end{array}$ & DeltaDays & $\begin{array}{l}\mathbf{B}_{\perp} \\
(\mathrm{m})\end{array}$ & No. & $\begin{array}{c}\text { Acquisition } \\
\text { Date } \\
\text { (ddmmyyyy) }\end{array}$ & DeltaDays & $\begin{array}{l}B_{\perp} \\
(\mathrm{m})\end{array}$ & No. & $\begin{array}{l}\text { Acquisition Date } \\
\text { (ddmmyyyy) }\end{array}$ & DeltaDays & $\begin{array}{l}\mathrm{B}_{\perp} \\
(\mathrm{m})\end{array}$ \\
\hline 1 & 18032017 & -576 & 77 & 32 & 30042018 & -168 & 64 & 62 & 07052019 & 204 & 93 \\
\hline 2 & 30032017 & -564 & 65 & 33 & 12052018 & -156 & -2 & 63 & 19052019 & 216 & 16 \\
\hline 3 & 11042017 & -552 & 3 & 34 & 24052018 & -144 & 28 & 64 & 31052019 & 228 & 20 \\
\hline 4 & 23042017 & -540 & 20 & 35 & 05062018 & -132 & 127 & 65 & 12062019 & 240 & 166 \\
\hline 5 & 05052017 & -528 & -25 & 36 & 17062018 & -120 & 103 & 66 & 06072019 & 264 & 104 \\
\hline 6 & 17052017 & -516 & 17 & 37 & 11072018 & -96 & 95 & 67 & 18072019 & 276 & 44 \\
\hline 7 & 29052017 & -504 & 110 & 38 & 23072018 & -84 & 62 & 68 & 30072019 & 288 & 90 \\
\hline 8 & 10062017 & -492 & 21 & 39 & 04082018 & -72 & 98 & 69 & 11082019 & 300 & -9 \\
\hline 9 & 22062017 & -480 & 21 & 40 & 16082018 & -60 & 75 & 70 & 23082019 & 312 & 1 \\
\hline 10 & 04072017 & -468 & 112 & 41 & 28082018 & -48 & 61 & 71 & 04092019 & 324 & 46 \\
\hline 11 & 09082017 & -432 & 54 & 42 & 09092018 & -36 & 60 & 72 & 16092019 & 336 & 106 \\
\hline 12 & 21082017 & -420 & 91 & 43 & 21092018 & -24 & 55 & 73 & 28092019 & 348 & -14 \\
\hline 13 & 02092017 & -408 & 50 & 44 & 03102018 & -12 & 115 & 74 & 10102019 & 360 & -110 \\
\hline 14 & 14092017 & -396 & 22 & 45 & 15102018 & 0 & 0 & 75 & 22102019 & 372 & -125 \\
\hline 15 & 26092017 & -384 & 43 & 46 & 27102018 & 12 & 53 & 76 & 03112019 & 384 & 19 \\
\hline 16 & 08102017 & -372 & 48 & 47 & 08112018 & 24 & 85 & 77 & 15112019 & 396 & -2 \\
\hline 17 & 20102017 & -360 & 72 & 48 & 20112018 & 36 & 85 & 78 & 27112019 & 408 & 38 \\
\hline 18 & 01112017 & -348 & 43 & 49 & 02122018 & 48 & 85 & 79 & 09122019 & 420 & 98 \\
\hline 19 & 13112017 & -336 & 91 & 50 & 14122018 & 60 & 142 & 80 & 21122019 & 432 & 87 \\
\hline 20 & 25112017 & -324 & 30 & 51 & 26122018 & 72 & 6 & 81 & 02012020 & 444 & 92 \\
\hline 21 & 07122017 & -312 & 140 & 52 & 07012019 & 84 & 74 & 82 & 14012020 & 456 & 40 \\
\hline 22 & 19122017 & -300 & 60 & 53 & 19012019 & 96 & 46 & 83 & 26012020 & 468 & 22 \\
\hline 23 & 31122017 & -288 & 135 & 54 & 31012019 & 108 & 40 & 84 & 07022020 & 480 & 36 \\
\hline 24 & 12012018 & -276 & 81 & 55 & 12022019 & 120 & 103 & 85 & 19022020 & 492 & 74 \\
\hline 25 & 24012018 & -264 & 78 & 56 & 24022019 & 132 & 29 & 86 & 02032020 & 504 & 93 \\
\hline 26 & 05022018 & -252 & 37 & 57 & 08032019 & 144 & -26 & 87 & 14032020 & 516 & 31 \\
\hline 27 & 17022018 & -240 & 15 & 58 & 20032019 & 156 & 26 & 88 & 26032020 & 528 & 41 \\
\hline 28 & 01032018 & -228 & 30 & 59 & 01042019 & 168 & 8 & 89 & 07042020 & 540 & 40 \\
\hline 29 & 13032018 & -216 & 101 & 60 & 13042019 & 180 & 75 & 90 & 19042020 & 552 & 14 \\
\hline 30 & 06042018 & -192 & 139 & 61 & 25042019 & 192 & -31 & 91 & 01052020 & 564 & 67 \\
\hline 31 & 18042018 & -180 & 126 & & & & & & & & \\
\hline
\end{tabular}

Table 2. Acquisition dates (format ddmmyyy) of the Sentinel-1 Sentinel-1 synthetic aperture radar SAR datasets in descending track. Delta days $=$ number of days between each acquisition date. $\mathrm{B} \perp=$ perpendicular baseline. The reference dates in descending tracks are shown in bold text.

\begin{tabular}{|c|c|c|c|c|c|c|c|c|c|c|c|}
\hline No. & $\begin{array}{l}\text { Acquisition Date } \\
\text { (ddmmyyyy) }\end{array}$ & DeltaDays & $\begin{array}{l}B_{\perp} \\
(\mathrm{m})\end{array}$ & No. & $\begin{array}{l}\text { AcquisitionD } \\
\text { (ddmmyyyy) }\end{array}$ & DeltaDays & $\begin{array}{l}B_{\perp} \\
(\mathrm{m})\end{array}$ & No. & $\begin{array}{l}\text { Acquisition Date } \\
\text { (ddmmyyyy) }\end{array}$ & DeltaDays & $\begin{array}{l}B_{\perp} \\
(\mathrm{m})\end{array}$ \\
\hline 1 & 26032017 & -600 & 22 & 31 & 02042018 & -228 & -20 & 61 & 27052019 & 192 & 24 \\
\hline 2 & 07042017 & -588 & 76 & 32 & 14042018 & -216 & 40 & 62 & 08062019 & 204 & 0 \\
\hline 3 & 19042017 & -576 & 83 & 33 & 26042018 & -204 & 0 & 63 & 20062019 & 216 & -7 \\
\hline 4 & 01052017 & -564 & 60 & 34 & 08052018 & -192 & 26 & 64 & 02072019 & 228 & 16 \\
\hline 5 & 13052017 & -552 & 0 & 35 & 20052018 & -180 & 0 & 65 & 14072019 & 240 & 29 \\
\hline 6 & 06062017 & -528 & 0 & 36 & 13062018 & -156 & 26 & 66 & 07082019 & 264 & 87 \\
\hline 7 & 18062017 & -516 & 48 & 37 & 25062018 & -144 & 26 & 67 & 19082019 & 276 & 84 \\
\hline 8 & 30062017 & -504 & 0 & 38 & 31072018 & -108 & -42 & 68 & 31082019 & 288 & -5 \\
\hline 9 & 12072017 & -492 & 0 & 39 & 24082018 & -84 & -1 & 69 & 12092019 & 300 & 0 \\
\hline 10 & 24072017 & -480 & -10 & 40 & 17092018 & -60 & 0 & 70 & 24092019 & 312 & 117 \\
\hline 11 & 05082017 & -468 & 41 & 41 & 29092018 & -48 & 30 & 71 & 06102019 & 324 & 94 \\
\hline 12 & 17082017 & -456 & 0 & 42 & 11102018 & -36 & 51 & 72 & 18102019 & 336 & 16 \\
\hline 13 & 29082017 & -444 & 57 & 43 & 23102018 & -24 & 0 & 73 & 30102019 & 348 & 19 \\
\hline 14 & 10092017 & -432 & 0 & 44 & 04112018 & -12 & 0 & 74 & 11112019 & 360 & 45 \\
\hline 15 & 22092017 & -420 & -4 & 45 & 16112018 & 0 & 0 & 75 & 23112019 & 372 & 0 \\
\hline 16 & 04102017 & -408 & 0 & 46 & 28112018 & 12 & -18 & 76 & 05122019 & 384 & 5 \\
\hline 17 & 16102017 & -396 & 16 & 47 & 10122018 & 24 & 3 & 77 & 17122019 & 396 & 54 \\
\hline 18 & 28102017 & -384 & 96 & 48 & 22122018 & 36 & 11 & 78 & 29122019 & 408 & 63 \\
\hline 19 & 09112017 & -372 & 0 & 49 & 03012019 & 48 & 0 & 79 & 10012020 & 420 & 35 \\
\hline 20 & 21112017 & -360 & 62 & 50 & 15012019 & 60 & 24 & 80 & 22012020 & 432 & 25 \\
\hline 21 & 03122017 & -348 & -2 & 51 & 27012019 & 72 & 0 & 81 & 03022020 & 444 & 11 \\
\hline 22 & 15122017 & -336 & -23 & 52 & 08022019 & 84 & 1 & 82 & 15022020 & 456 & 24 \\
\hline 23 & 27122017 & -324 & -50 & 53 & 20022019 & 96 & 34 & 83 & 27022020 & 468 & -8 \\
\hline 24 & 08012018 & -312 & 0 & 54 & 04032019 & 108 & 101 & 84 & 10032020 & 480 & 91 \\
\hline 25 & 20012018 & -300 & 0 & 55 & 16032019 & 120 & 23 & 85 & 22032020 & 492 & 72 \\
\hline 26 & 01022018 & -288 & 14 & 56 & 28032019 & 132 & 0 & 86 & 03042020 & 504 & 33 \\
\hline 27 & 13022018 & -276 & 39 & 57 & 09042019 & 144 & -12 & 87 & 15042020 & 516 & 0 \\
\hline 28 & 25022018 & -264 & 0 & 58 & 21042019 & 156 & 133 & 88 & 27042020 & 528 & 0 \\
\hline 29 & 09032018 & -252 & -36 & 59 & 03052019 & 168 & 82 & 89 & 09052020 & 540 & 0 \\
\hline 30 & 21032018 & -240 & -68 & 60 & 15052019 & 180 & 42 & & & & \\
\hline
\end{tabular}




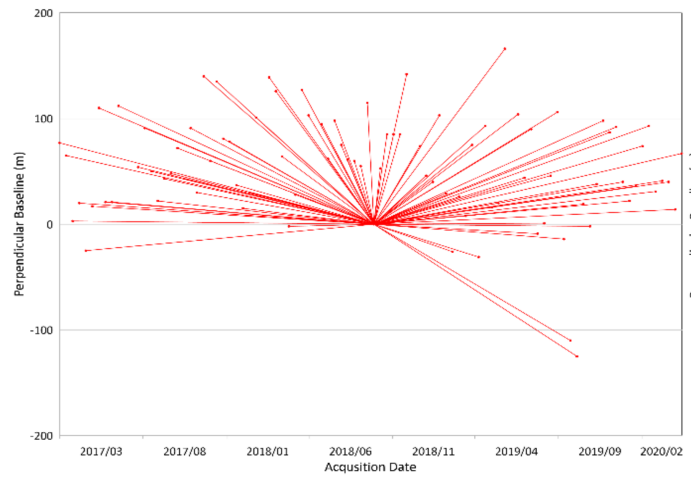

(a)

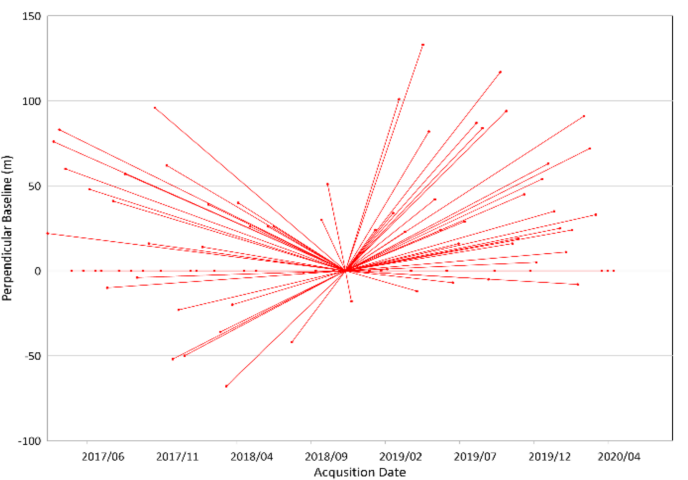

(b)

Figure 2. Perpendicular baseline graph from (a) ascending track and (b) descending track.

\subsection{Land Subsidence Conditioning Factors}

In total, 14 land subsidence conditioning factors consisting of geological, geomorphological, topographical, and hydrological data were chosen as the conditioning factors (Table 3) in this study as they are considered the main factors influencing land subsidence $[11,13,14]$. Each factor was classified using the quantile method, and the factors with different cell size resolutions were resampled into raster datasets with $30 \mathrm{~m}$ cell size from each conditioning factor to standardize each factor's resolution.

Table 3. Land subsidence conditioning factors in the study area. DEM, digital elevation model; SRTM, Shuttle Radar Topography Mission.

\begin{tabular}{|c|c|c|}
\hline Category & Factor & Source \\
\hline Hydrological factors & Groundwater drawdown & $\begin{array}{l}\text { Groundwater Conservation Center of } \\
\text { Indonesia, The Ministry of Energy } \\
\text { and Mineral Resources }\end{array}$ \\
\hline Hydrological factors & Rainfall intensity & $\begin{array}{l}\text { Meteorology, Climatology, } \\
\text { and Geophysical Agency of Indonesia }\end{array}$ \\
\hline Land cover factors & Road network & $\begin{array}{c}\text { Geospatial Information Agency of } \\
\text { Indonesia }\end{array}$ \\
\hline Hydrological factors & River network & $\begin{array}{c}\text { Geospatial Information Agency of } \\
\text { Indonesia }\end{array}$ \\
\hline Geological factors & Faults & $\begin{array}{c}\text { Geospatial Information Agency of } \\
\text { Indonesia }\end{array}$ \\
\hline Land cover factors & Land use & $\begin{array}{c}\text { The Ministry of Environment and Forestry } \\
\text { of Indonesia }\end{array}$ \\
\hline Geological factors & Lithology & $\begin{array}{c}\text { The Ministry of Energy and Mineral } \\
\text { Resources }\end{array}$ \\
\hline Topographical factors & Elevation & DEM SRTM 1 Arc-Second Global \\
\hline Topographical factors & Slope & DEM SRTM 1 Arc-Second Global \\
\hline Topographical factors & Aspect & DEM SRTM 1 Arc-Second Global \\
\hline Geomorphological factors & Profile curvature & DEM SRTM 1 Arc-Second Global \\
\hline Geomorphological factors & Plan curvature & DEM SRTM 1 Arc-Second Global \\
\hline Hydrological factors & Topographic wetness index & DEM SRTM 1 Arc-Second Global \\
\hline
\end{tabular}

A recent study in Jakarta found that the leading causes of land subsidence in Jakarta are groundwater extraction, the load of buildings and construction, natural consolidation of alluvium soil, and tectonic activities [3]. In this study, groundwater drawdown data were collected from the Groundwater Conservation Center, The Ministry of Energy and Mineral Resources of Indonesia. The observation of groundwater drawdown data is carried out periodically through an automatic water level record (AWLR) system. The annual change in groundwater level from 2019 to 2020 was calculated from 15 monitoring wells, and the map was constructed (Figure 3a) using the inverse 
distance weighting (IDW) interpolation method from the annual change in groundwater level data. The obtained groundwater drawdown data in this study were insufficient compared to the study area due to the limited monitoring wells over the study area. Although the available data are few, the use of groundwater drawdown data is essential to determine the relationship between land subsidence and groundwater extraction.

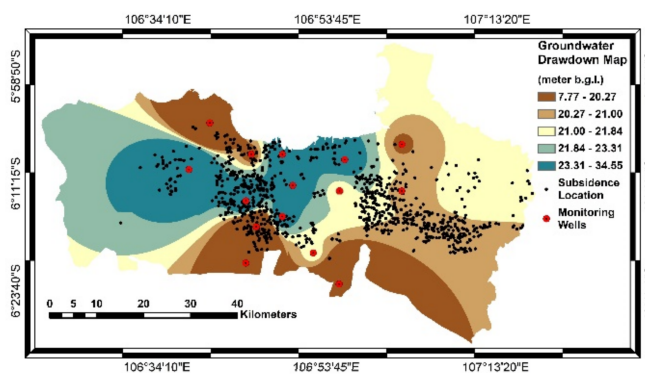

(a)

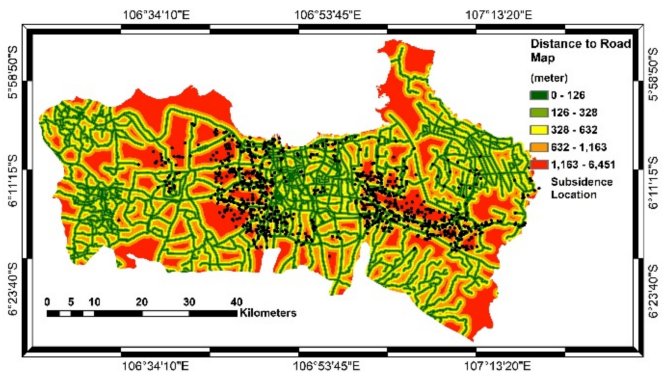

(c)

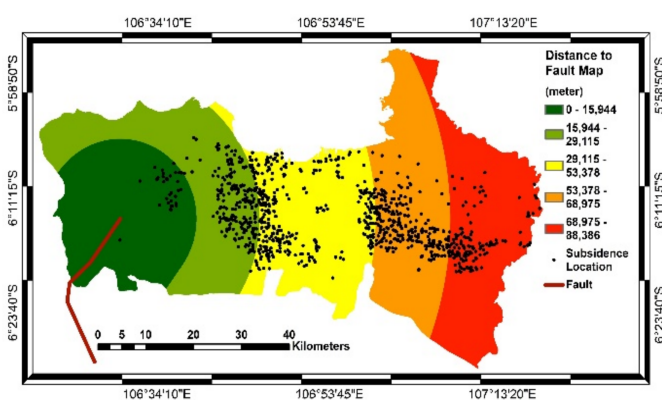

(e)

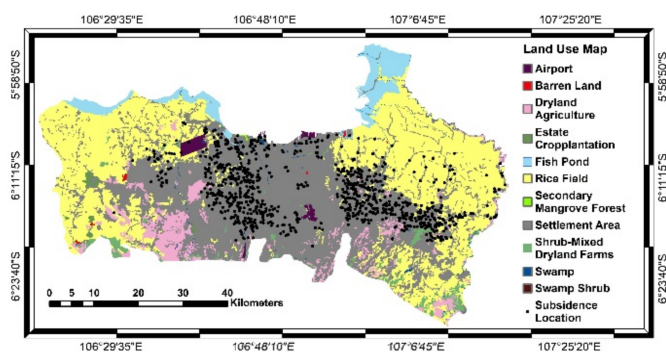

(g)

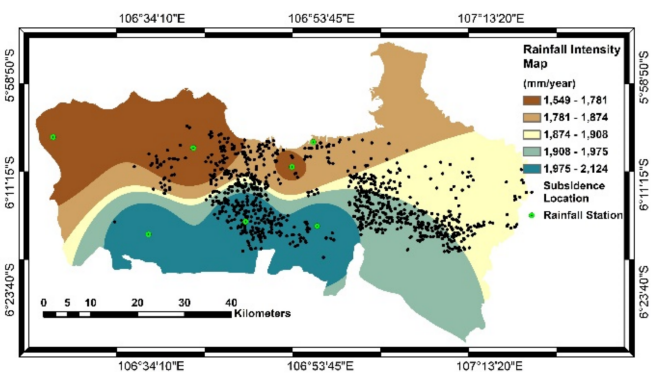

(b)

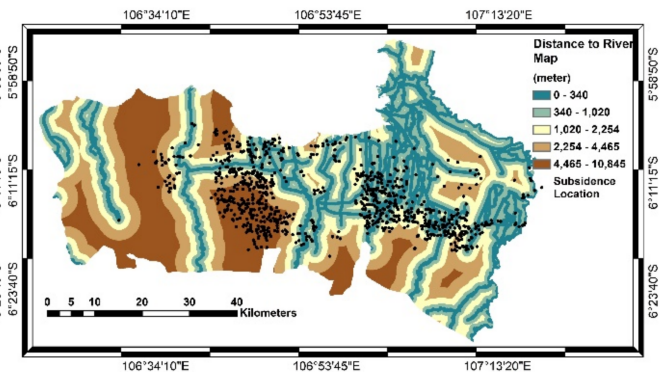

(d)

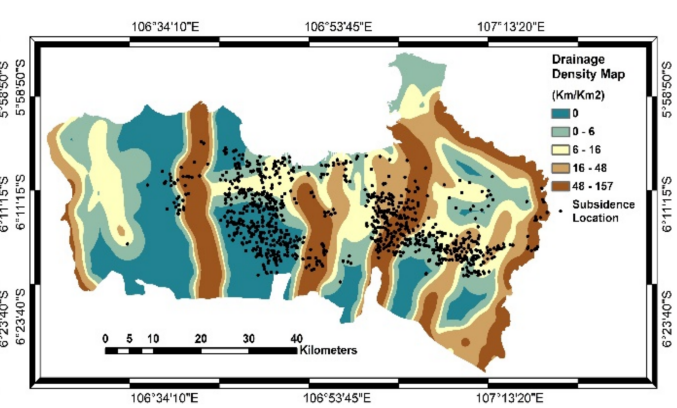

(f)

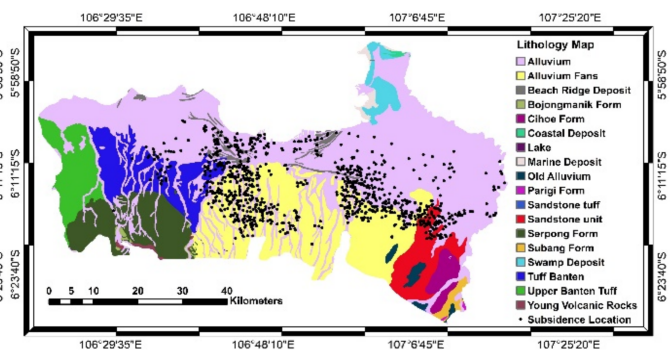

(h) 


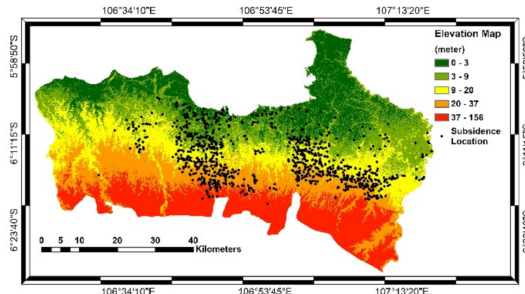

(i)

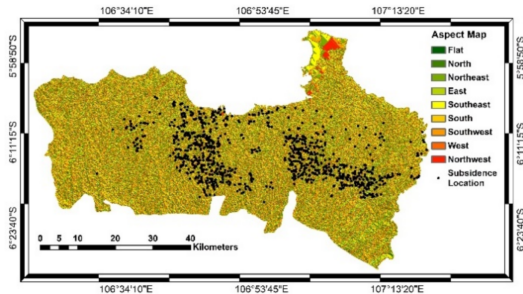

(k)

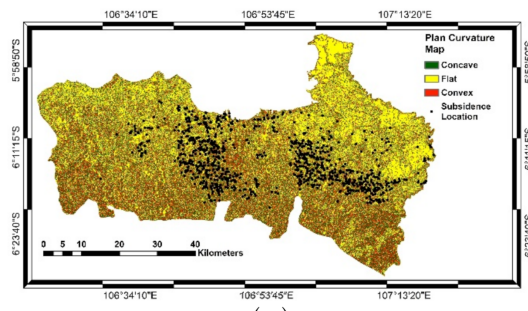

(m)

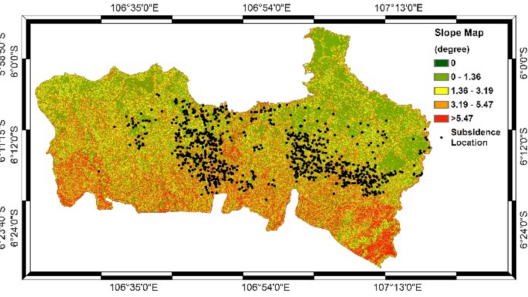

(j)

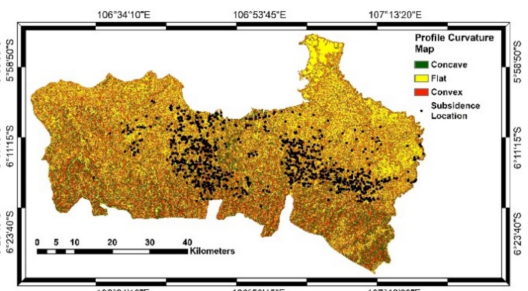

(1)

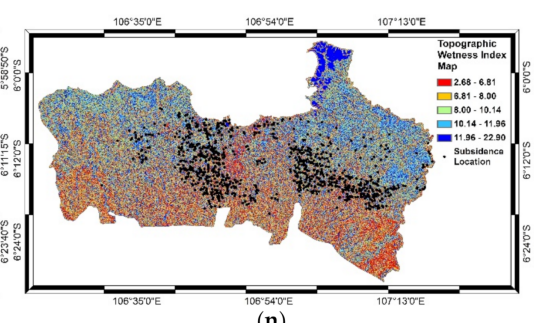

(n)

Figure 3. Land subsidence conditioning factors: (a) groundwater drawdown; (b) rainfall intensity; (c) distance to roads; (d) distance to rivers; (e) distance to faults; (f) drainage density; (g) land use; (h) lithology; (i) elevation; (j) slope; (k) aspect; (1) profile curvature; (m) plan curvature; (n) topographic wetness index.

The groundwater level can increase due to conditional factors indirectly associated with land subsidence, such as rainfall, distance from a river, and river density, which can recharge the groundwater level $[13,50]$. Four years of daily rainfall data (from 2017 to 2020) from seven weather stations were acquired from the Indonesian Meteorology, Climatology, and Geophysical Agency of Indonesia, and the annual rainfall intensity was calculated and interpolated using the IDW tool in geographic information system (GIS) software (ArcGIS; ESRI, Redlands, CA, USA) (Figure 3b). However, the availability of rainfall data was limited compared to the study area due to the cost and constraints of acquiring data. Nevertheless, the utilization of the rainfall data in this study is important to correlate the topographical factor related to the infiltration flow affecting the soil's strength.

Road, river, and fault networks were acquired from the Geospatial Information Agency of Indonesia from the main road map, main river map, and fault map at a scale of 1:250,000 of polygonal-shaped data using the Atlas map of Indonesia. The information on the location of roads, rivers, and faults was used to construct a distance map (Figure 3c, Figure 3d, and Figure 3e, respectively) using the Euclidean distance tool, and the maps were classified using the quantile method to provide suitable classes within a $30 \mathrm{~m}$ cell size. The drainage density or river map density was estimated using the kernel density tool (Figure 3f). Distance to the road and land use are related to urban development in Jakarta, which can affect land subsidence [3]. The land-use map (Figure 3g) was acquired from the Ministry of Environment and Forestry of Indonesia that used Landsat data to generate a land cover map. The geological parameters describe the spatial correlation of lithological landform and land subsidence in Jakarta as being caused by the compaction of the alluvium soil landform [3]. The lithology map (Figure 3h) was acquired from the Geological Atlas map of Indonesia from the Ministry of Energy and Mineral Resources, and the polygonal-shaped map was converted into a raster map with $30 \mathrm{~m}$ cell size using GIS tools. 
The topographical map, which includes elevation, slope, aspect, profile curvature, plan curvature, and topographic wetness index (TWI) (Figure 3i, Figure 3j, Figure 3k, Figure 31, Figure 3m, and Figure 3n, respectively) data extracted from the digital elevation model (DEM) of the Shuttle Radar Topography Mission (SRTM) [51], was constructed using the basic terrain analysis tools. Elevation influences the hydrological properties and soil moisture, whereby a lower-elevation area possibly gains more precipitation than a higher-elevation area $[13,14]$. The slope is associated with land subsidence because it affects the infiltration of rainfall (a steeper surface slope decreases infiltration) [13,21], and the aspect is the second derivative of the slope that has a relationship with land subsidence because the slope aspect affects the strength of the soil due to the moisture preservation and the amount of vegetation [11]. Profile curvature is associated with flow speed, sediment, and erosion quantity, while plan curvature is perpendicular to the slope and indirectly affects land subsidence by influencing convergence and divergence of flow across the surface [13]. The TWI defines the degree of deposition of water at a specific site [52]. The topographical factors extracted from the SRTM DEM are widely used as conditioning factors in land subsidence susceptibility mapping [11-13,28].

The relationship of land subsidence occurrence with the conditioning factors in each class is described in Table 4. A ratio greater than 1 denotes that the class in the conditioning factor is more correlated with the land subsidence occurrence [11]. The calculation of frequency ratio shows that the land subsidence occurred in areas with groundwater level data between 20.27 and 21.00 and between 23.31 and $34.55 \mathrm{~m}$ below ground level, while land subsidence also occurred in areas with more annual rainfall intensity due to the recharge of groundwater level and the usage of groundwater. Areas between 0 and $126 \mathrm{~m}$ with roads were more correlated with land subsidence occurrence. The land subsidence areas correlated with fault distance were between 15,944 and 68,975 $\mathrm{m}$ from the fault location. There were three drainage density classes correlated with land subsidence occurrence and settlement areas correlated with land subsidence. In terms of lithological factors, alluvium, alluvium fans, beach ridge deposits, and sandstone landforms were considered more correlated with the land subsidence occurrences. There were three classes in the elevation map, four classes in the aspect map, two classes in the slope map, one class in the plan curvature, one class in the profile curvature, and three classes in the topographic wetness index map correlated with land subsidence occurrences.

Table 4. Relationship between land subsidence occurrence and conditioning factors using frequency ratio (FR) model.

\begin{tabular}{cccccc}
\hline \multirow{2}{*}{ No. } & $\begin{array}{c}\text { Conditioning } \\
\text { Factor }\end{array}$ & Class/Category & $\begin{array}{c}\text { Ratio each } \\
\text { Class }\end{array}$ & $\begin{array}{c}\text { Ratio of } \\
\text { Occurrence }\end{array}$ & FR \\
\hline \multirow{3}{*}{1} & Groundwater & $7.77-20.27$ & 0.1831 & 0.1201 & 0.6561 \\
& drawdown & $20.27-21.00$ & 0.2021 & 0.2953 & 1.4616 \\
& (m below & $21.00-21.84$ & 0.2361 & 0.2127 & 0.9009 \\
& ground level) & $21.84-23.31$ & 0.1914 & 0.1282 & 0.6697 \\
& $23.31-34.55$ & 0.1874 & 0.2437 & 1.3003 \\
\hline & & $1,549-1,781$ & 0.1999 & 0.1009 & 0.5046 \\
& Rainfall & $1,781-1,874$ & 0.1945 & 0.1635 & 0.8404 \\
& intensity map & $1,874-1,908$ & 0.1977 & 0.2241 & 1.1338 \\
& (mm/year) & $1,908-1,975$ & 0.2090 & 0.3069 & 1.4680 \\
& & $1,975-2,124$ & 0.1989 & 0.2047 & 1.0290 \\
\hline \multirow{3}{*}{3} & & $0-126$ & 0.2114 & 0.2201 & 1.0412 \\
& Distance to & $126-328$ & 0.1978 & 0.1964 & 0.9931 \\
& road map $(\mathrm{m})$ & $328-632$ & 0.1972 & 0.1943 & 0.9853 \\
& & $632-1,163$ & 0.1968 & 0.1964 & 0.9979 \\
\end{tabular}


Table 4. Cont.

\begin{tabular}{|c|c|c|c|c|c|}
\hline No. & $\begin{array}{c}\text { Conditioning } \\
\text { Factor }\end{array}$ & Class/Category & $\begin{array}{c}\text { Ratio each } \\
\text { Class }\end{array}$ & $\begin{array}{c}\text { Ratio of } \\
\text { Occurrence }\end{array}$ & FR \\
\hline \multirow{5}{*}{4} & \multirow{5}{*}{$\begin{array}{l}\text { Distance to } \\
\text { river map (m) }\end{array}$} & $0-340$ & 0.2009 & 0.2262 & 1.1262 \\
\hline & & $340-1,020$ & 0.1999 & 0.2369 & 1.1848 \\
\hline & & $1,020-2,254$ & 0.1998 & 0.2030 & 1.0159 \\
\hline & & $2,254-4,465$ & 0.1997 & 0.1422 & 0.7120 \\
\hline & & $4,465-10,845$ & 0.1997 & 0.1917 & 0.9601 \\
\hline \multirow{5}{*}{5} & \multirow{5}{*}{$\begin{array}{c}\text { Distance to } \\
\text { fault map (m) }\end{array}$} & $0-15,944$ & 0.2000 & 0.0386 & 0.1929 \\
\hline & & $15,944-29,115$ & 0.2000 & 0.2029 & 1.0145 \\
\hline & & $29,155-53,378$ & 0.2000 & 0.3375 & 1.6874 \\
\hline & & $53,378-68,975$ & 0.2000 & 0.2845 & 1.4223 \\
\hline & & $68,975-88,386$ & 0.2000 & 0.1366 & 0.6829 \\
\hline \multirow{5}{*}{6} & \multirow{5}{*}{$\begin{array}{c}\text { Drainage } \\
\text { density } \\
\left(\mathrm{km} / \mathrm{km}^{2}\right)\end{array}$} & 0 & 0.2331 & 0.2408 & 1.0331 \\
\hline & & $0-6$ & 0.1917 & 0.1655 & 0.8632 \\
\hline & & $6-16$ & 0.1917 & 0.2071 & 1.0801 \\
\hline & & $16-48$ & 0.1917 & 0.2101 & 1.0960 \\
\hline & & $48-157$ & 0.1917 & 0.1765 & 0.9206 \\
\hline \multirow{11}{*}{7} & \multirow{11}{*}{ Land-use map } & Airport & 0.0084 & 0.0022 & 0.2644 \\
\hline & & Barren land & 0.0009 & 0.0004 & 0.4666 \\
\hline & & Dryland agriculture & 0.0594 & 0.0076 & 0.1275 \\
\hline & & Estate crop plantation & 0.0035 & 0.0003 & 0.0739 \\
\hline & & Fish pond & 0.0475 & 0.0012 & 0.0250 \\
\hline & & Rice field & 0.3979 & 0.0650 & 0.1634 \\
\hline & & Secondary mangrove forest & 0.0003 & 0.0001 & 0.3295 \\
\hline & & Settlement area & 0.4572 & 0.9194 & 2.0110 \\
\hline & & Shrub-mixed dryland farms & 0.0198 & 0.0028 & 0.1440 \\
\hline & & Swamp & 0.0051 & 0.0009 & 0.1831 \\
\hline & & Swamp shrub & 0.0000 & 0.0000 & 0.1441 \\
\hline \multirow{13}{*}{8} & \multirow{13}{*}{ Lithology map } & Alluvium & 0.5020 & 0.5577 & 1.1111 \\
\hline & & Alluvium fans & 0.1966 & 0.3200 & 1.6274 \\
\hline & & Beach ridge deposits & 0.0153 & 0.0341 & 2.2385 \\
\hline & & Bojongmanik form & 0.0022 & 0.0000 & 0.0000 \\
\hline & & Cihoe form & 0.0161 & 0.0002 & 0.0149 \\
\hline & & Coastal deposit & 0.0013 & 0.0000 & 0.0000 \\
\hline & & Lake & 0.0001 & 0.0000 & 0.1178 \\
\hline & & Marine deposits & 0.0052 & 0.0000 & 0.0024 \\
\hline & & Old alluvium & 0.0074 & 0.0002 & 0.0239 \\
\hline & & Parigi form & 0.0005 & 0.0000 & 0.0000 \\
\hline & & Sandstone tuff & 0.0001 & 0.0000 & 0.0000 \\
\hline & & Sandstone unit & 0.0405 & 0.0440 & 1.0873 \\
\hline & & Serpong form & 0.0703 & 0.0014 & 0.0198 \\
\hline
\end{tabular}


Table 4. Cont.

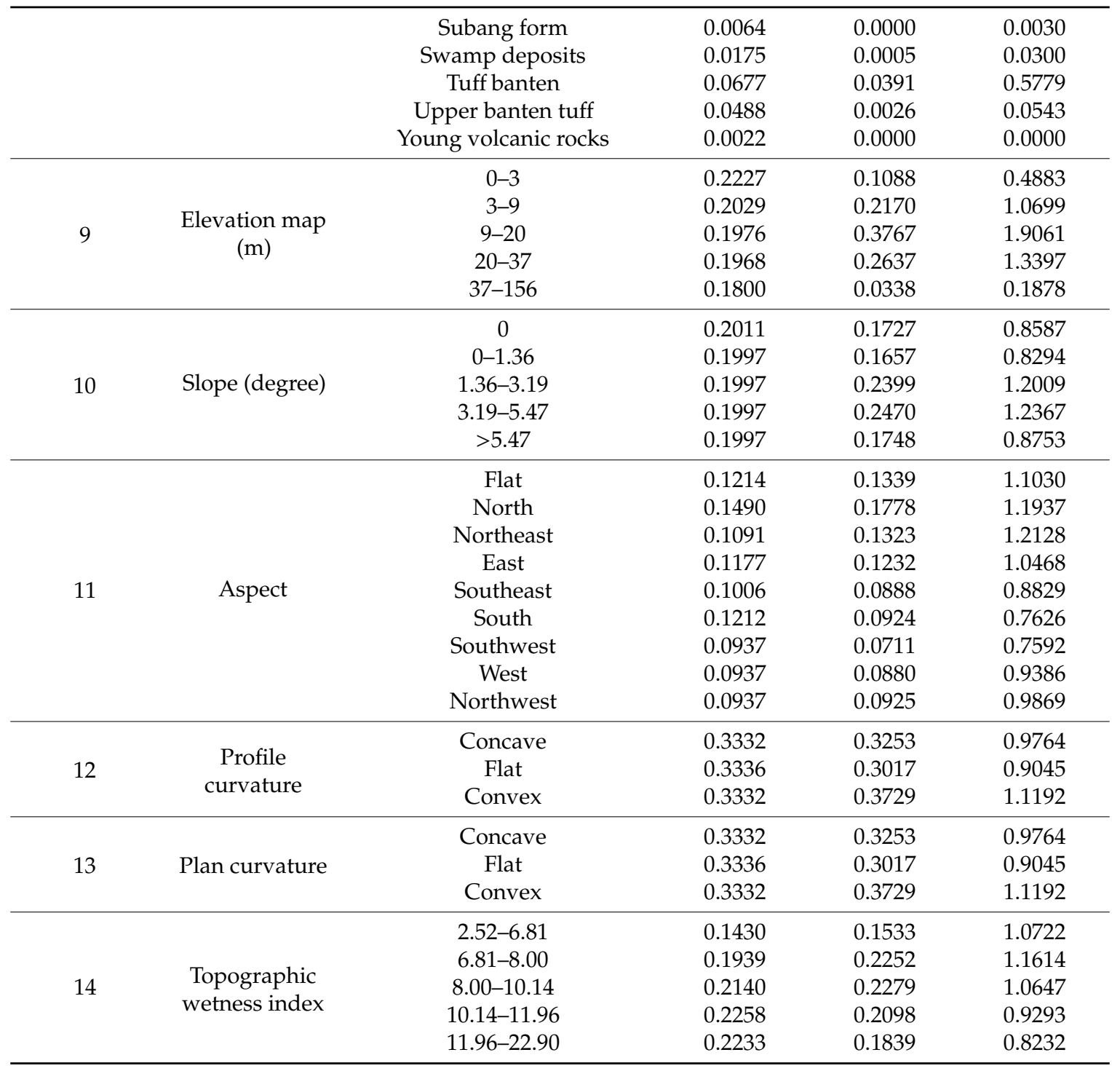

\subsection{Illustration of Methodology}

The methods to generate land subsidence susceptibility maps using functional and meta-ensemble algorithms are described below and illustrated in Figure 4.

1. Land subsidence occurrences were identified by exploiting Sentinel-1 SAR datasets from 2017 to 2020 from both ascending and descending tracks using time-series InSAR techniques based on the StaMPS algorithm. The persistent scatterer points from co-registered single master images showing a deformation value were used as the land subsidence inventory map.

2. Preparation of training and testing datasets was conducted by randomly dividing the persistent scatterer (PS) points of time-series InSAR showing a vertical deformation into 50\% training data to generate land subsidence susceptibility models and $50 \%$ testing data to validate the land subsidence susceptibility map, as done in other studies finding optimal results $[28,53]$. The distribution of training and test data is shown in Figure $1 \mathrm{~b}$.

3. Preparation of land subsidence conditioning factors for spatial correlation analysis was done using the frequency ratio method to find the correlation between each factor and land subsidence occurrence [53]. We used each model's ratio value and then used as the conditioning factors related to land subsidence occurrences. First, the conditioning factors were classified using 
quantile methods in GIS tools with a similar environment of $30 \mathrm{~m}$ cell size for each factor; then, the number of subsidence occurrences in each class was calculated using the cross-tabulation tool in GIS. Next, we calculated the ratio between the percentage of pixels of each conditioning factor class and the percentage of subsidence occurrence pixels to obtain the FR value as follows:

$$
\text { Frequency Ratio }=\frac{\% \text { of class conditioning factor }}{\% \text { of land subsidence occurrence }}
$$

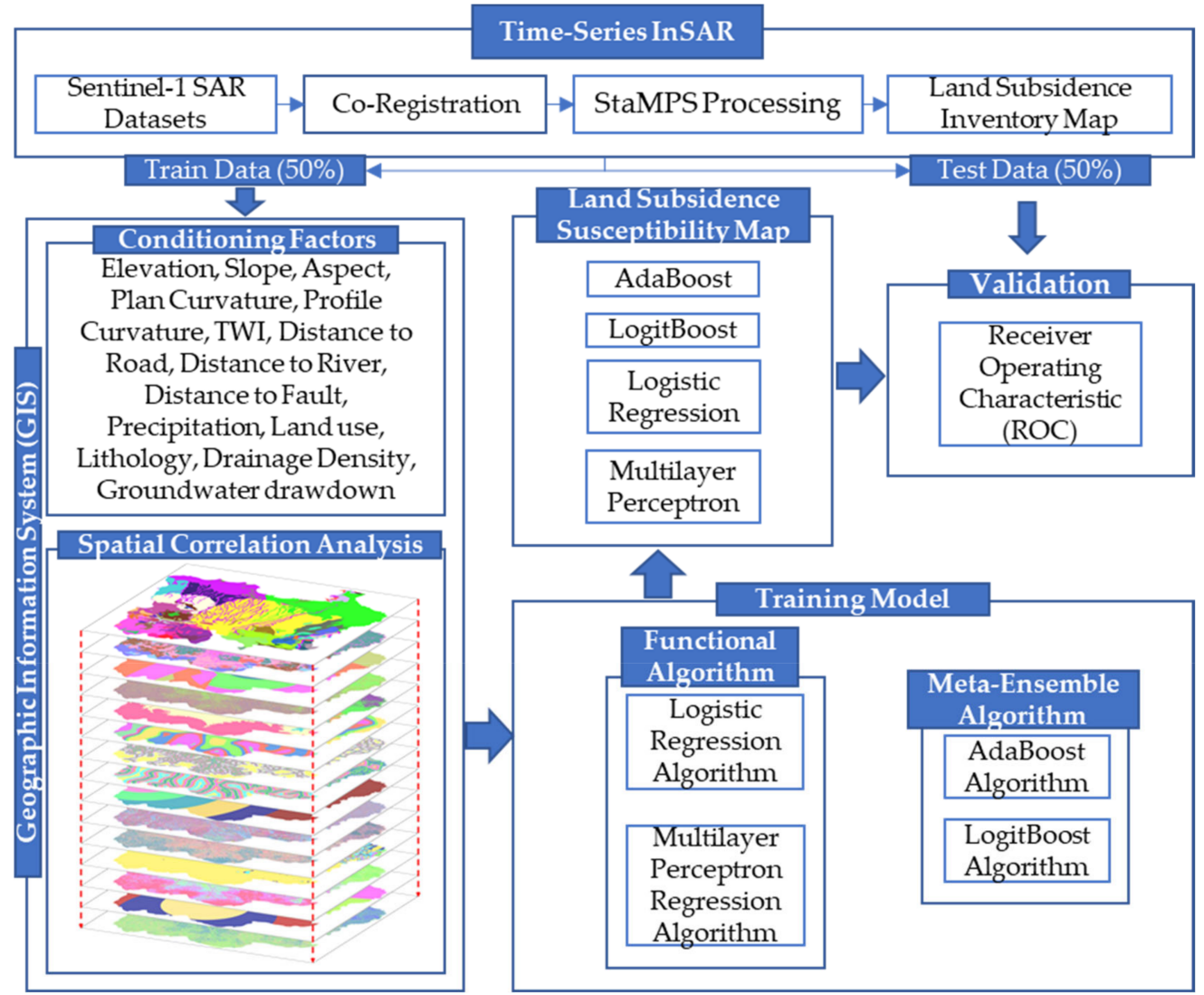

Figure 4. The study workflow.

4. The conditioning factors consisting of frequency ratio values were used to generate land subsidence susceptibility models using two functional algorithms (logistic regression and multilayer perceptron) and two meta-ensemble algorithms (AdaBoost and LogitBoost).

5. After all land subsidence susceptibility maps were generated, all maps were validated using the test data prepared before and analyzed using ROC curve analysis.

\subsection{StaMPS Processing}

StaMPS (Stanford Method for Persistent Scatterers) is an analysis method used to facilitate the generation of time-series deformation images of all terrains, including nonurban areas. The StaMPS algorithm uses the spatial correlation of phase measurements rather than a functional temporal model to identify PS pixels. StaMPS processing does not use a model to describe how the displacement rate varies with time. To identify PS pixels in a single master stack of interferograms, StaMPS uses the phase characteristics from the dominant point scatterer in each area and creates interferograms from SAR images. It also reduces decorrelation [54]. Thus, the StaMPS algorithm can identify and extract the deformation signal from stable pixels in all terrains. 
The slave images in the acquired SAR datasets were resampled to perfectly match the master image through a co-registration process before generating an interferogram. The co-registration process was applied to two different images to produce refined SAR images, which were then cropped to focus only on the area of interest. Next, differential InSAR (DInSAR) images were generated by subtracting the topographic InSAR images generated using the interferograms from the topographic phases of the SRTM DEM [55,56]. We used the PS method to measure the displacement of the earth's surface [57] to generate the time-series deformation map. The main processes generated a single master stack of interferograms and topographic phase removal [33].

The StaMPS algorithm is shown in Figure 5. Multiple images were co-registered to generate a single master image for the ascending track on 15 October 2018 and the descending track on 16 November 2018; co-registered images with the topographic phases removed were subjected to amplitude and phase noise analysis to derive a subset comprising all PS pixels, with weeding performed using a threshold value of 0.4 . The wrapped phase of the selected pixels was corrected for the spatially uncorrelated look-angle error. The phase was then unwrapped, and PS outputs were generated. The deformation map from the line of sight (LOS) displacement could be converted into vertical deformation data [58,59] by assuming the horizontal deformation as very small compared to the vertical deformation caused by land subsidence [60-62]. Recent studies using GPS and leveling surveys reported that the land subsidence in Jakarta shows a vertical deformation [7], and a vertical deformation pattern was also found in research using InSAR to monitor land subsidence in Jakarta [1,46]; hence, the deformation from the line of sight (LOS) in this study could be assumed as negligible and could be converted directly into vertical deformation value using Equation (2) by dividing the displacement or deformation from the line of sight $\left(\mathrm{d}_{\mathrm{LOS}}\right)$ by the cosine of incident angle $(\theta)$ from the radar signal. The results of vertical deformation were assigned a negative value from the initial ground-level observation point, indicating that the land subsidence occurred vertically at that point [9].

$$
\mathrm{V}=\frac{\mathrm{d}_{\mathrm{LOS}}}{\cos \theta}
$$

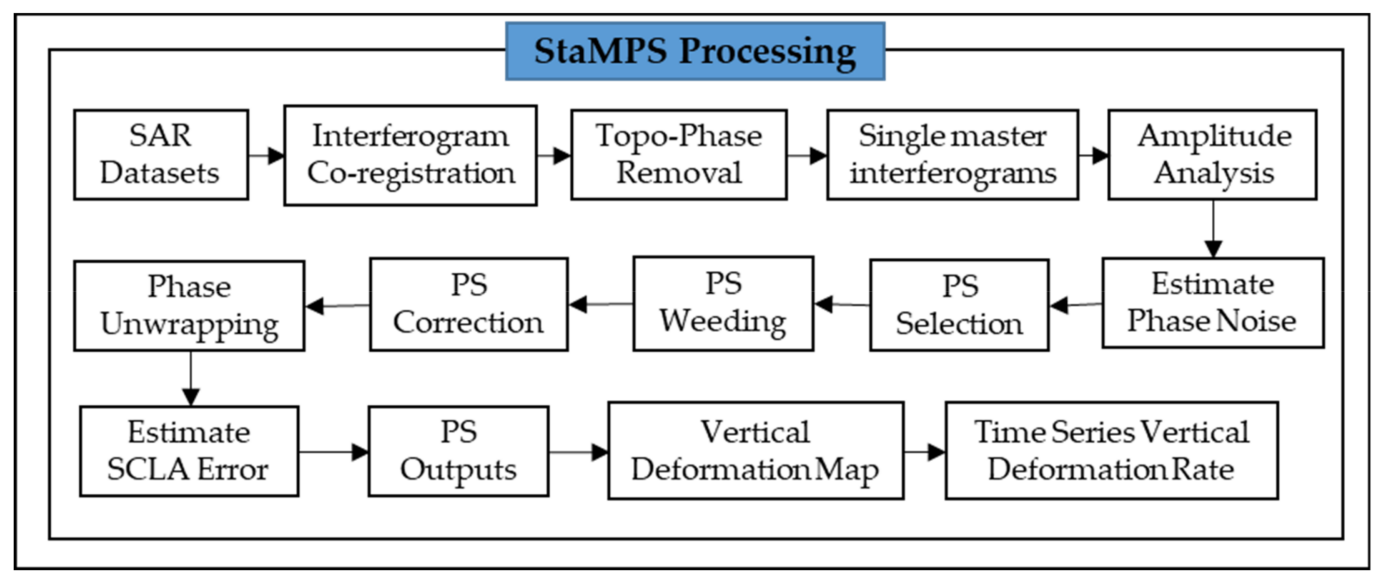

Figure 5. Flowchart of Stanford Method for Persistent Scatterers (StaMPS) Processing.

\subsection{AdaBoost}

AdaBoost is a machine learning algorithm introduced by Freund and Schapire (1997) [63]. AdaBoost's classifier uses an adaptive resampling technique that produces a series of individual classifiers to classify training samples accurately. The frequency of variables selected by a weak learner was examined, and the relative importance of the variables could be determined [64]. AdaBoost combines multiple weak learners to derive a single strong learner by repeatedly calling a weak classifier and adjusting the attributed weight to the sample. The new classifier focuses more on the misclassified 
sample as the misclassified sample is increased compared to the correct sample. The final weight is obtained by adding or subtracting the updated weight in each iteration. The final model is obtained by dividing each final weight by the total adjusted weight [65]. The general form of the AdaBoost algorithm is as follows [66]:

1. Start with weights $w_{i}=\frac{1}{N}$ for $i=1, \ldots, N$;

2. Repeat this step for $\mathrm{m}=1, \ldots, \mathrm{M}$ :

a. Fit the classifier $\mathrm{f}_{\mathrm{m}}(\mathrm{x}) \in\{-1,1\}$ using weights $\mathrm{w}_{\mathrm{i}}$ with the training data;

b. Compute $\operatorname{err}_{\mathrm{m}}=\mathrm{E}_{\mathrm{w}}\left[1_{\left(\mathrm{y} \neq \mathrm{f}_{\mathrm{m}}(\mathrm{x})\right)}\right], \mathrm{c}_{\mathrm{m}}=\log \left(\frac{1-\operatorname{err}_{\mathrm{m}}}{\operatorname{err}_{\mathrm{m}}}\right)$;

c. $\quad$ Set $\mathrm{w}_{\mathrm{i}} \leftarrow \mathrm{w}_{\mathrm{i}} \exp \left[\mathrm{c}_{\mathrm{m}} 1_{\left(\mathrm{y} \neq \mathrm{f}_{\mathrm{m}}(\mathrm{x})\right)}\right], \mathrm{i}=1,2, \ldots, \mathrm{N}$, and renormalize so that $\sum_{\mathrm{i}} \mathrm{w}_{\mathrm{i}}=1$;

3. Output the classifier: $\operatorname{sign}\left[\sum_{\mathrm{m}=1}^{\mathrm{M}} \mathrm{c}_{\mathrm{m}} \mathrm{f}_{\mathrm{m}}(\mathrm{x})\right]$.

\subsection{LogitBoost}

LogitBoost is a modified version of the AdaBoost algorithm, introduced by Friedman, Hastie, and Tibshirani [66], where the exponential loss function is replaced with the log-likelihood loss function. This method reduces classification error and is less sensitive to noise $[28,67]$. LogitBoost can handle multiple class problems and uses a regression scheme as the base learner for classification [64]. The general form of the LogitBoost algorithm is as follows [66]:

1. Start with weights $\mathrm{w}_{\mathrm{i}}=\frac{1}{\mathrm{~N}}$ for $\mathrm{i}=1,2, \ldots, \mathrm{N}, \mathrm{F}(\mathrm{x})=0$, and probability estimates $\mathrm{p}\left(\mathrm{x}_{\mathrm{i}}\right)=\frac{1}{2}$;

2. Repeat this step for $\mathrm{m}=1, \ldots, \mathrm{M}$ :

a. Compute the working response and weights:

$$
\begin{aligned}
\mathrm{l}_{\mathrm{i}} & =\frac{\mathrm{y}_{\mathrm{i}}^{*}-\mathrm{p}\left(\mathrm{x}_{\mathrm{i}}\right)}{\mathrm{p}\left(\mathrm{x}_{\mathrm{i}}\right)\left(1-\mathrm{p}\left(\mathrm{x}_{\mathrm{i}}\right)\right)}, \\
\mathrm{w}_{\mathrm{i}} & =\mathrm{p}\left(\mathrm{x}_{\mathrm{i}}\right)\left(1-\mathrm{p}\left(\mathrm{x}_{\mathrm{i}}\right)\right) ;
\end{aligned}
$$

b. Fit the function by weighted least-squares regression of $1_{i}$ to $x_{i}$ using weight $w_{i}$;

c. Update the function as follows:

$$
\begin{aligned}
& \mathrm{f}(\mathrm{x}) \leftarrow \mathrm{f}(\mathrm{x})+\frac{1}{2} \mathrm{f}_{\mathrm{m}}(\mathrm{x}), \\
& \mathrm{p}(\mathrm{x}) \leftarrow \frac{\mathrm{e}^{\mathrm{f}(\mathrm{x})}}{\mathrm{e}^{\mathrm{f}(\mathrm{x})}+\mathrm{e}^{-\mathrm{f}(\mathrm{x})}} ;
\end{aligned}
$$

3. Output the classifier: $\operatorname{sign}[F(x)]=\operatorname{sign}\left[\sum_{m=1}^{M} f_{m}(x)\right]$.

\subsection{Logistic Regression}

Logistic regression is a statistical method used to find the best model to describe the correlation between a dependent variable and several independent variables. This method's advantage is that the variables do not need to be normally distributed [68]. It also offers several ways of selecting the best predictor for use in the P probability model $[69,70]$. The equations describing the logistic regression are as follows $[28,69-71]$ :

$$
f(x)=\operatorname{logit}(P)=\ln \left[\frac{P}{1-P}\right]=c_{0}+c_{1} x_{1}+\ldots+c_{n} x_{n},
$$




$$
\mathrm{P}=\frac{1}{1+\mathrm{e}^{-\mathrm{f}(\mathrm{x})}}=\frac{1}{1+\mathrm{e}^{-\left(\mathrm{c}_{0}+\mathrm{c}_{1} x_{1}+\ldots+\mathrm{c}_{\mathrm{n}} \mathrm{x}_{\mathrm{n}}\right)}},
$$

where $f(x)$ is a linear combination function called $\operatorname{logit}(P), P$ is the probability of subsidence occurrence, $1-\mathrm{P}$ is the probability that subsidence will not occur, $\mathrm{x}_{1}, \mathrm{x}_{2}, \ldots, \mathrm{x}_{\mathrm{n}}$ are input variables, $\mathrm{c}_{0}$ is the model intercept, and $c_{1}, \ldots, c_{n}$ are the approximated coefficients of regression.

\subsection{Multilayer Perceptron}

The multilayer perceptron is a machine learning algorithm based on the ANN technique that consists of input layers, hidden layers, and output layers [72]. The advantages of the multilayer perceptron algorithm are as follows: the distribution of the training data does not require any assumptions, most inputs are selected during the training process based on the weight adjustment, and the relative importance of the various input measures does not need to be determined [73]. The equation representing the multilayer perceptron for land subsidence classification is as follows $[28,72,73]$ :

$$
\mathrm{m}=\mathrm{f}(\mathrm{c}),
$$

where $f(c)$ is a hidden function that is optimized during the training process for a given network architecture via the adjustable weights, and $c=c_{i}$ for $i=1, \ldots, 14$, which is a vector containing 14 land subsidence conditioning factors.

\section{Results}

\subsection{Land Subsidence Inventory Map}

The mean vertical deformation maps for Jakarta shown in Figure $6 \mathrm{a}, \mathrm{b}$ were derived by time-series InSAR analysis based on the StaMPS algorithm. We overlaid a true color red/green/blue (RGB) composite image from Sentinel-2 taken on 28 August 2020. Six areas from both ascending and descending tracks showed high deformation; thus, we plotted a deformation trend for these areas.

The vertical deformation rate in the ascending track at Point P1 (Figure 6c) represents the Kosambi area, which subsided $189.48 \mathrm{~mm}$ from 2017 to 2020. Point P2 (Figure 6c) represents the Cengkareng area, which subsided $184.02 \mathrm{~mm}$ from 2017 to 2020. Point P3 (Figure 6e) represents the Ciledug area, which subsided up to $155.22 \mathrm{~mm}$ from 2017 to 2020. Point P4 (Figure 6e) represents the Penjaringan area, which subsided $148.36 \mathrm{~mm}$ from 2017 to 2020. Point P5 (Figure 6g) represents the Bekasi area, which subsided $128.17 \mathrm{~mm}$ from 2017 to 2020. Point P6 (Figure 6g) represents the Cikarang area, which subsided $271.84 \mathrm{~mm}$ from 2017 to 2020 .

The vertical deformation rate in the descending track at Point P1 (Figure 6d) represents the Kosambi area, which subsided $210.07 \mathrm{~mm}$ from 2017 to 2020. Point P2 (Figure 6d) represents the Cengkareng area, which subsided $216.19 \mathrm{~mm}$ from 2017 to 2020. Point P3 (Figure 6f) represents the Ciledug area, which subsided up to $155.92 \mathrm{~mm}$ from 2017 to 2020. Point P4 (Figure 6f) represents the Penjaringan area, which subsided $148.31 \mathrm{~mm}$ from 2017 to 2020. Point P5 (Figure 6h) represents the Bekasi area, which subsided $107.19 \mathrm{~mm}$ from 2017 to 2020. Point P6 (Figure 6h) represents the Cikarang area, which subsided $257.94 \mathrm{~mm}$ from 2017 to 2020.

Figure $6 \mathrm{~g}$, h show that the deformation pattern was mostly linear. However, Figure $6 \mathrm{c}-\mathrm{f}$, representing the Kosambi, Cengkareng, Ciledug, and Penjaringan areas, show quite periodic subsidence with the standard deviation of the vertical deformation rate being higher than the vertical deformation rate in Figure $6 \mathrm{~g}, \mathrm{~h}$. These results occurred due to the seasonal effect of groundwater extraction, and those areas were surrounded by a residential area that mostly used groundwater as the water source. Meanwhile, P6 is one of the most significant industrial areas in Indonesia. The mean vertical deformation maps from ascending and descending tracks were compared to validate the accuracy of the land subsidence inventory map using the StaMPS algorithm, and the result showed a good correlation in Figure $6 \mathrm{i}$ with a coefficient of correlation $\left(\mathrm{R}^{2}\right)$ up to 0.9584 between ascending and descending tracks. 


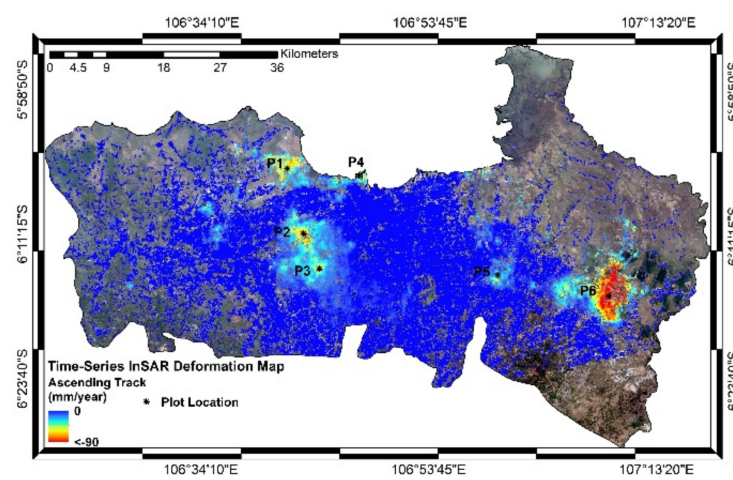

(a)

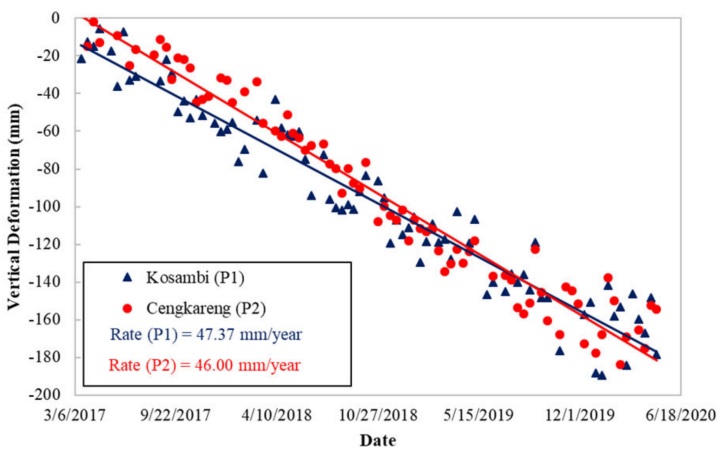

(c)

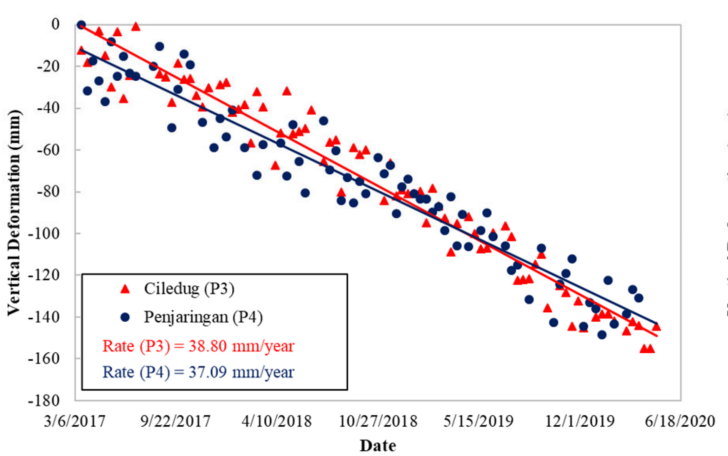

(e)

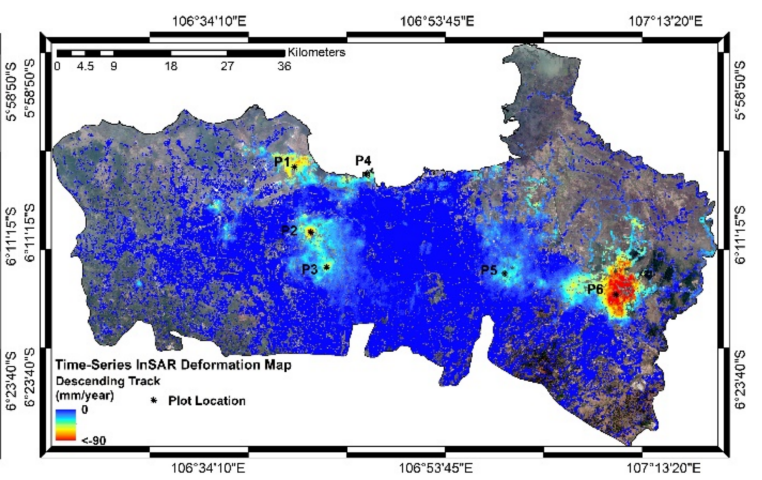

(b)

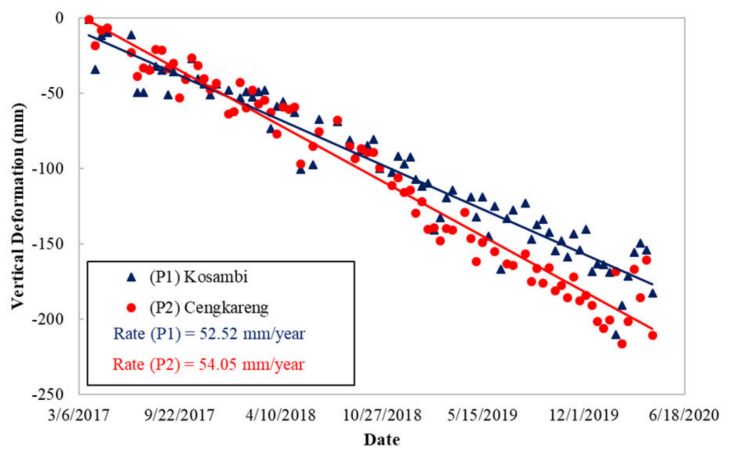

(d)

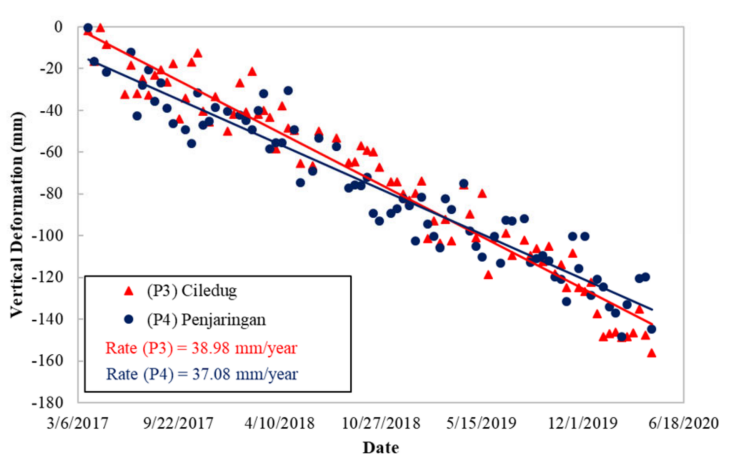

(f) 


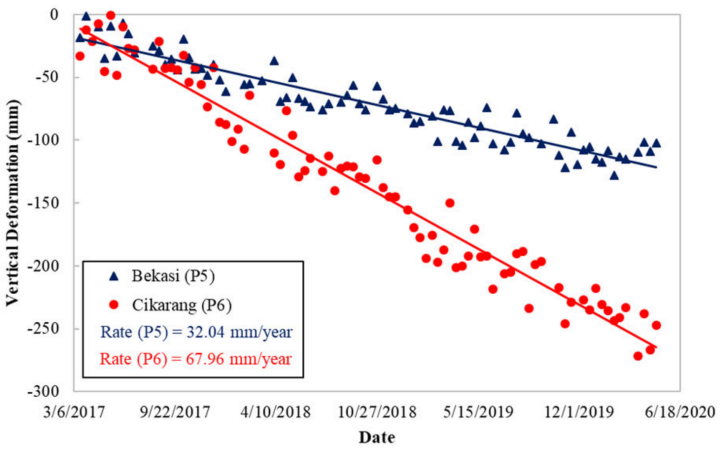

$(\mathrm{g})$

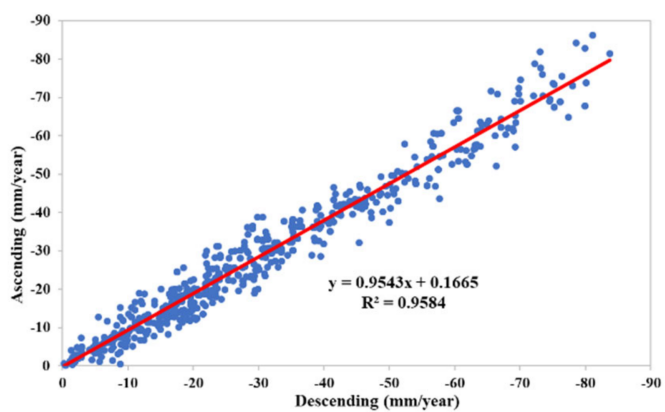

(i)

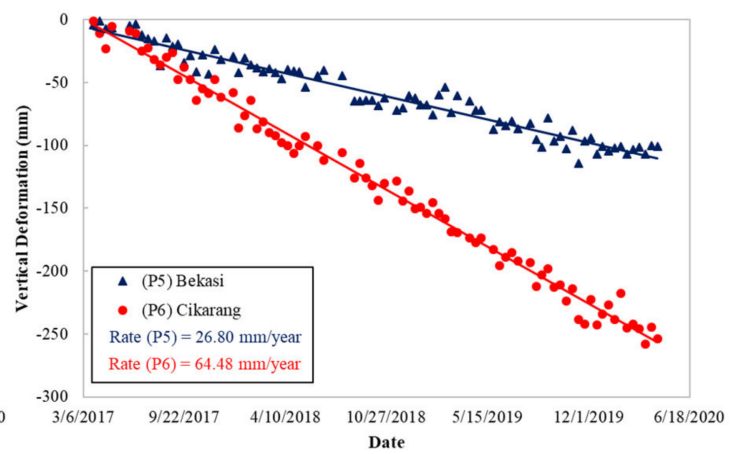

(h)

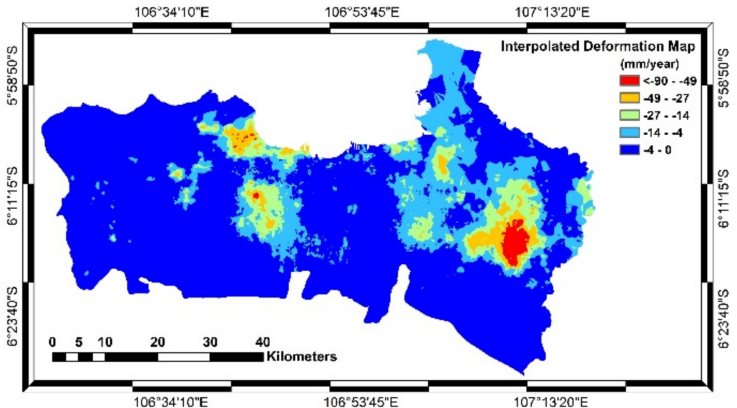

(j)

Figure 6. Mean vertical deformation map for Jakarta depicted using Sentinel-2 image in (a) ascending tracks and (b) descending tracks; the vertical deformation rate at P1 (Kosambi) and P2 (Cengkareng) in (c) ascending and (d) descending tracks; the vertical deformation rate at P3 (Ciledug) and P4 (Penjaringan) in ascending (e) and descending (f) tracks; the vertical deformation at P5 (Bekasi) and P4 (Cikarang) in ascending (g) and descending tracks (h). (i) The comparison of mean vertical deformation between ascending and descending tracks. (j) Kriging interpolation of time-series deformation map from mean vertical deformation map of descending track, resulting in the extension of the land subsidence inventory map; the blue area is considered as the nonoccurrence area of land subsidence.

The persistent scatterer density of both tracks in the east and west areas was relatively low due to them being wetland areas and more vegetated than other areas. The SAR dataset used in this study from Sentinel-1 SAR C-band data with $5.5 \mathrm{~cm}$ wavelength could not deeply penetrate beneath the trees. Thus, to overcome that limitation, the interpolation of the persistent scatterer points from the descending track was constructed using kriging interpolation in GIS tools to provide land subsidence information over the study area as shown in Figure 6j [74].

\subsection{Land Subsidence Susceptibility Map}

The land subsidence susceptibility model's performance depended on the calculated parameters (Table 5) for optimization used in this study.

A land subsidence susceptibility map was generated using 14 land subsidence conditioning factors, training data from our land subsidence inventory map, and four different algorithms: LogitBoost (Figure 7a), AdaBoost (Figure 7b), logistic regression (Figure 7c), and multilayer perceptron (Figure 7d). Land subsidence susceptibility indices were generated for all unique pixels in the study area. The susceptibility indices were reclassified using the quantile method to identify feature pairs in five susceptibility classes: very low, low, moderate, high, and very high $[28,64]$. 
Table 5. Calculated parameters for the algorithms used in this study.

\begin{tabular}{cc}
\hline Algorithm & Parameters \\
\hline AdaBoost & The number of iterations: 10; seed: 1; weight threshold: 100. \\
\hline LogitBoost & $\begin{array}{c}\text { Number of iterations: 10; Seed: } 1 \text {; weight threshold: } 100 ; \\
\text { likelihood threshold: }-1.7976 \text { E308; shrinkage: } 1.0 ; \text { max } \\
\text { threshold: } 3 \text {; thread pool: } 1 \text {; thread to batch prediction: } 1 .\end{array}$ \\
\hline Logistic Regression & Ridge: 1.0E-8; max iterations: -1 ; number of decimal places: 4. \\
\hline Multilayer Perceptron & $\begin{array}{c}\text { Hidden layers: a; learning rate: } 0.3 ; \text { momentum: } 0.2 ; \text { number } \\
\text { of decimal places: } 2 ; \text { seed: } 0 \text {; training time: } 500 ; \text { validation set } \\
\text { size: } 0 ; \text { validation threshold: } 20 .\end{array}$ \\
\hline
\end{tabular}

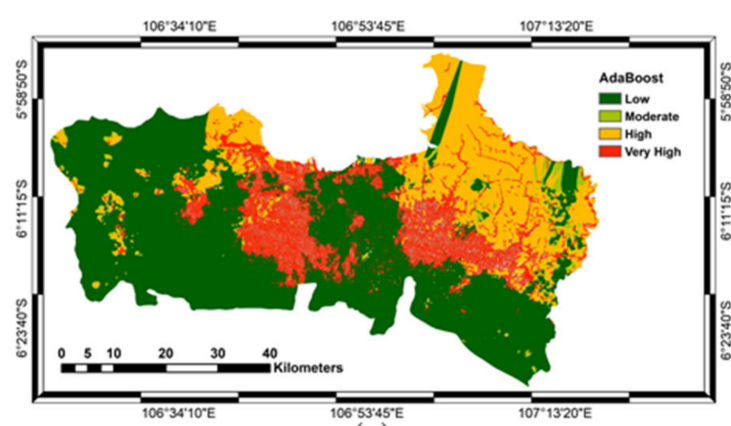

(a)

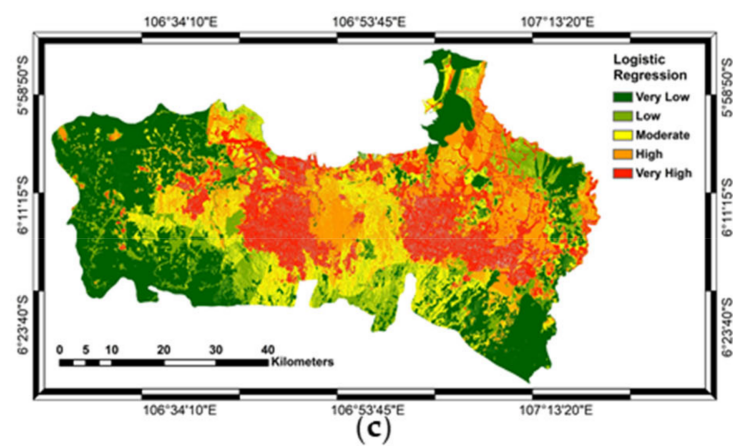

(c)

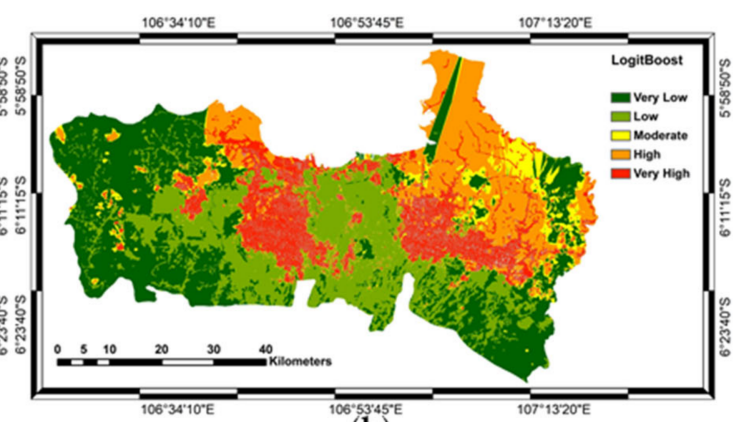

(b)

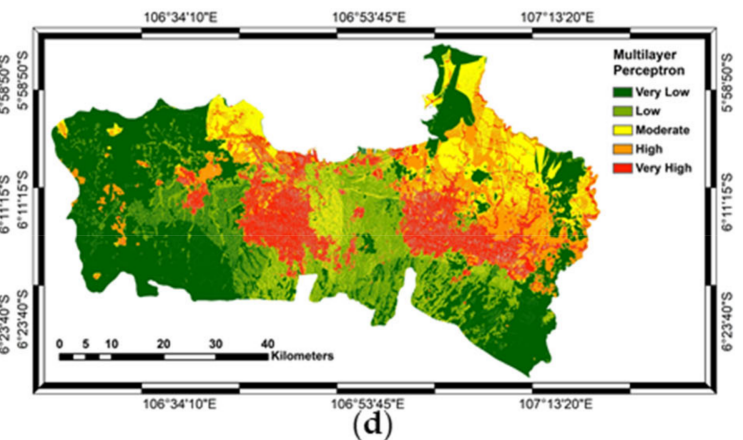

Figure 7. Land subsidence susceptibility map for Jakarta, generated using four different algorithms: (a) AdaBoost, (b) LogitBoost, (c) logistic regression, and (d) multilayer perceptron.

The proportion of very high susceptibility land was quite similar for all four algorithms. However, the map generated by AdaBoost differed from those of the other three methods because the AdaBoost model could only classify susceptibility into four classes due to the limits of the probability range. Therefore, the very low susceptibility class was excluded. The susceptibility class proportions (pixel distributions) are shown in Figure 8. For the Adaboost algorithm, the proportions were 0\%, $57.88 \%, 2.54 \%, 22.02 \%$, and $17.56 \%$ for the very low, low, moderate, high, and very high classes, respectively; the respective values for the LogitBoost algorithm were $33.33 \%, 27.09 \%, 7.03 \%, 16.77 \%$, and $15.78 \%$, and those for the logistic regression algorithm were $32.62 \%, 13.86 \%, 16.44 \%, 18.51 \%$, and $18.57 \%$. Finally, the multilayer perceptron algorithm's respective values were $40.64 \%, 18.70 \%$, $14.02 \%, 13.42 \%$, and $13.23 \%$.

The distribution of pixels in the very high class and high class in Figure 8 showed similar results for each algorithm, resulting in the maps of these classes being quite similar. The very high class was considered to be the land subsidence areas shown in the mean vertical deformation map in Figure $6 a, b$, with similarity seen because of the training data used in this study being acquired from the land subsidence inventory map with a large spatial resolution, which allowed more effectively 
defining the land subsidence area in the susceptibility map. The moderate and high classes were considered land subsidence areas in the future, and the very low and low classes were areas with the lowest probability of land subsidence in the future. The difference between the moderate class from AdaBoost and that from other algorithms is that AdaBoost did not consider other areas far from the land subsidence occurrences. Other algorithms showed that residential areas located in alluvium landforms had a reasonable possibility of land subsidence.

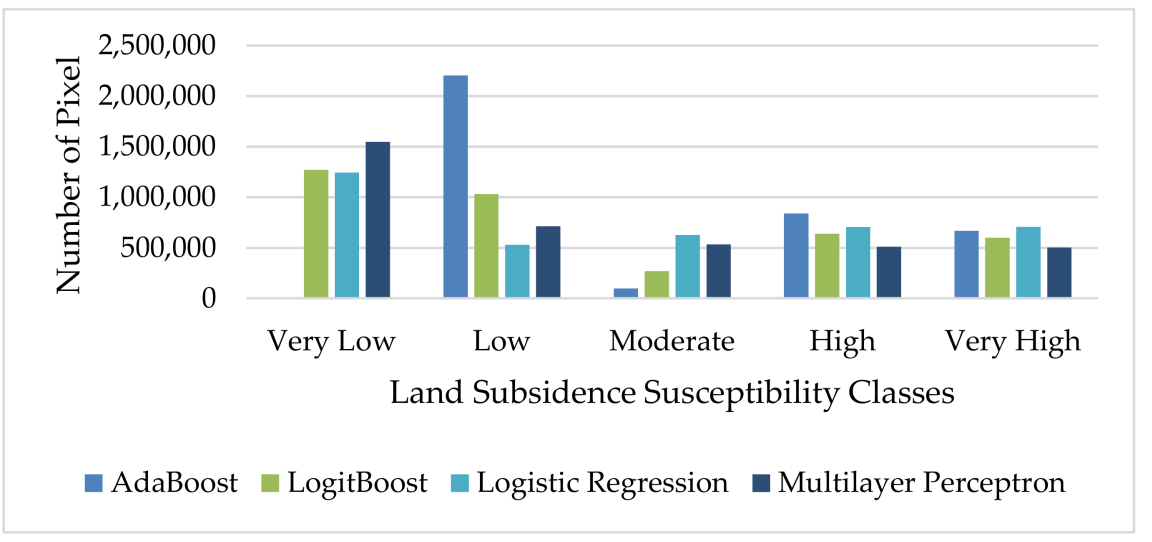

Figure 8. Proportions of susceptibility classes for land subsidence susceptibility maps generated using four different machine learning algorithms.

\subsection{Model Validation}

The accuracy of all four algorithms in this study was evaluated by ROC curve analysis [12,17]. ROC curve analysis is a standard way of validating the probability models used to generate land subsidence susceptibility maps, according to the area under the curve (AUC) [22,28]. Higher values indicate more accurate and reliable models. If the AUC, which ranges from 0 to 1 , is lower than 0.5 , the model is considered unacceptably inaccurate [75].

Land subsidence susceptibility maps produced using functional (AdaBoost, LogitBoost) and meta-ensemble (logistic regression and multilayer perceptron) algorithms were compared. The ROC curves for the four algorithms are shown in Figure 9. The largest AUC of 0.811 was from the AdaBoost algorithm (blue line in Figure 9). The multilayer perceptron algorithm had the next largest AUC (0.800; purple line in Figure 9), followed by the logistic regression (0.794; green line in Figure 9) and LogitBoost algorithms (0.791; red line in Figure 9).

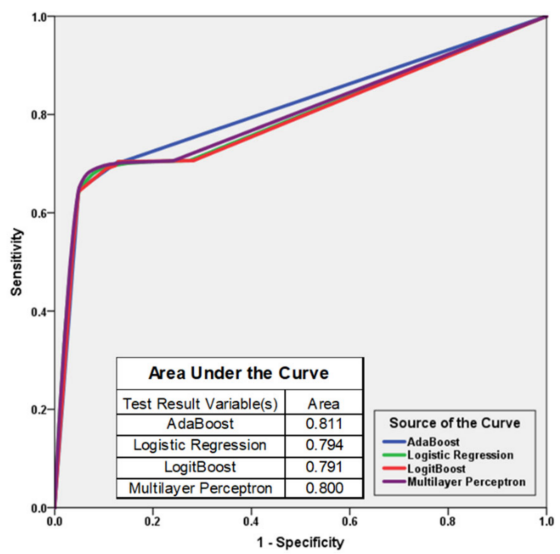

Figure 9. Receiver operating characteristic (ROC) curves for the land subsidence susceptibility maps produced by functional (logistic regression and multilayer perceptron) and meta-ensemble (AdaBoost and LogitBoost) algorithms. 
Variables having at least one tie between the positive actual state group and the negative actual state group can bias the results. Since all of the AUC values were higher than 0.5, the land subsidence susceptibility maps produced by all algorithms used in this study are acceptable for predicting high-risk subsidence areas in Jakarta [75]. However, the AdaBoost algorithm map had the best performance.

\section{Discussion}

\subsection{Land Subsidence Inventory Map}

A land subsidence inventory map was successfully created through time-series InSAR analysis of Sentinel-1 datasets, using the StaMPS algorithm. The map is displayed as a vertical deformation map in Figure $6 \mathrm{a}, \mathrm{b}$ for descending and ascending tracks. The comparison was made to validate the mean vertical deformation's accuracy used as a land subsidence inventory map. A coefficient of correlation of 0.9584 was found. As stated above, there were six high-deformation areas (Figure $6 c-h$ ) within ascending and descending tracks, which were equally affected (in terms of subsidence) by increased groundwater usage and existing buildings [3].

Figure $6 \mathrm{~g}$,h show areas with largely linear deformation rates, the standard deviations of which were smaller than those of the area shown in Figure 6c-f. The periodic subsidence shown was affected due to the variable climate in Jakarta, which is generally characterized by high rainfall but a dry summer. In the rainy season, the groundwater level of all aquifers beneath Jakarta increases, which manifests as deformation, i.e., an uplift in the ground level due to a change in the underlying material's thickness [34,76-79].

As shown by the land subsidence occurrence (Figure 6a,b) and groundwater drawdown (Figure 3a) data, land subsidence for P1-P5, which are between 20.58 and $34.55 \mathrm{~m}$ below ground level, correlated with the groundwater level. The correlation between land subsidence and groundwater level might have been stronger if groundwater level data were available for the whole study area. The groundwater level is deepest for P1 and P2, ranging from 22.47 to $34.55 \mathrm{~m}$. P6 has more significant deformation because it contains the largest industrial estate in Indonesia.

Jakarta is mostly situated on young alluvial soil (Figure 3h), which cannot tolerate the maximum compression force of many buildings [9]. Thus, compaction of the unconsolidated alluvial soil occurs and is exacerbated by groundwater extraction (because pore pressure is reduced, leading to further clay compaction) [80,81].

\subsection{Land Subsidence Susceptibility Map}

The method used to create land subsidence susceptibility maps strongly affects the quality of the mapping. Machine learning techniques are effective $[12,13,28,64]$. In particular, the method used to generate training and testing data is important. Accurate land subsidence inventory maps can be obtained using InSAR; we combined InSAR and GIS spatial data to produce an accurate land subsidence susceptibility map [12]. Nevertheless, the distribution data of groundwater drawdown and rainfall intensity data from the interpolation process might not represent the whole study area. They could have affected the spatial distribution of the raster map. Access to the monitoring wells and rainfall station outside the Jakarta area could provide more accurate analysis to determine the relationship between those factors and land subsidence.

The land subsidence susceptibility maps of all four algorithms used in this study could be ordered according to the accuracy and time taken to build the model due to the similarities in the conditioning factors, training and testing data, and study area [28]. We used ROC curve analysis to assess the accuracy of the maps. The AUC data showed that the AdaBoost algorithm had the highest susceptibility class predictive accuracy of $81.1 \%$, which was $1.1 \%$ higher than the multilayer perceptron algorithm, $1.7 \%$ higher than the logistic regression algorithm, and $2 \%$ higher than the LogitBoost algorithm. Since the accuracy of the algorithms used was so closely related, we analyzed the time consumption of data preparation needed to build the model. The AdaBoost algorithm needed $218.63 \mathrm{~s}$ to build the model, 
the LogitBoost algorithm needed $174.94 \mathrm{~s}$ to build the model, logistic regression needed $16667.96 \mathrm{~s}$ or $4.63 \mathrm{~h}$ to build the model, and multilayer perceptron needed $47,538.65 \mathrm{~s}$ or $13.20 \mathrm{~h}$ to build the model, thus identifying the LogitBoost algorithm as the fastest.

However, the LogitBoost algorithm had the lowest prediction accuracy $(79.10 \%)$. The Adaboost algorithm needed $218.63 \mathrm{~s}$ or $3.64 \mathrm{~min}$ to build the model, along with having the highest prediction accuracy of $81.10 \%$ in the ROC curve analysis. Logistic regression needed $4.63 \mathrm{~h}$ to build the model, along with a prediction accuracy of about $79.40 \%$, and the multilayer perceptron needed $13.20 \mathrm{~h}$, along with a prediction accuracy of $80 \%$. The maps generated using LogitBoost, logistic regression, and multilayer perceptron (Figure $7 \mathrm{~b}-\mathrm{d}$, respectively) showed similar weights and indicated that the settlement area was at a high risk of land subsidence. The land-use map generated in this study indicated a relatively strong correlation between land subsidence and urban development, likely due to excessive groundwater extraction in urban areas [3,6,7]. Our map could be used by local environmental authorities and those in charge of urban development to identify areas with high subsidence risk. The method of combining SAR and GIS spatial data to generate land subsidence susceptibility maps employed in this study could be applied to other regions.

\section{Conclusions}

We generated a land subsidence inventory map using a time-series InSAR method based on the StaMPS algorithm from Sentinel-1 SAR datasets in ascending and descending tracks. The comparison of both tracks was conducted, finding a coefficient of correlation between the two tracks of 0.9548 . The inventory map could be used as a training and testing dataset to create a land subsidence susceptibility map for Jakarta using meta-ensemble (AdaBoost and LogitBoost) and functional (logistic regression and multilayer perceptron) machine learning algorithms. We created a land subsidence inventory map through time-series InSAR analysis of Sentinel-1 SAR datasets using the StaMPS algorithm. The land subsidence susceptibility map produced by the AdaBoost machine learning algorithm had higher accuracy (AUC $=0.811$ ) and only need $3.64 \mathrm{~min}$ to build the model compared with the maps created using the other algorithms (multilayer perceptron, $\mathrm{AUC}=0.800$; logistic regression, AUC $=0.794$; LogitBoost, AUC = 0.791). LogitBoost was the fastest algorithm in building the model but had the lowest predictive accuracy. Logistic regression and multilayer perceptron needed 4.63 and $13.20 \mathrm{~h}$, respectively, to build the model. All of the maps showed acceptable accuracy, as the AUC values were all higher than 0.5 ; thus, they can all be used for analyzing land subsidence susceptibility in Jakarta. Our approach based on time-series InSAR analysis, machine learning, and GIS spatial data yielded reasonable predictions of areas with high risk of land subsidence. Further research could use alternative algorithms and conditioning factors to generate land subsidence susceptibility maps in other regions.

Author Contributions: Conceptualization, C.-W.L., and W.L.H.; methodology, C.-W.L., A.R.A., and W.L.H.; software, A.R.A. and W.L.H.; validation, C.-W.L. and W.L.H.; formal analysis, W.L.H.; investigation, C.-W.L.; resources, C.-W.L.; data curation, C.-W.L. and W.L.H.; writing-original draft preparation, W.L.H.; writing-review and editing, C.-W.L., A.R.A., and W.L.H.; visualization, C.-W.L., A.R.A., and W.L.H.; supervision, C.-W.L.; project administration, C.-W.L.; funding acquisition, C.-W.L. All authors read and agreed to the published version of the manuscript.

Funding: This research was supported by a grant from the National Research Foundation of Korea provided by the government of Korea (No. 2019R1A2C1085686).

Conflicts of Interest: The authors declare no conflict of interest. The funders had no role in the design of the study; in the collection, analyses, or interpretation of data; in the writing of the manuscript, or in the decision to publish the results. 


\section{References}

1. Chaussard, E.; Amelung, F.; Abidin, H.; Hong, S.-H. Sinking cities in Indonesia: ALOS PALSAR detects rapid subsidence due to groundwater and gas extraction. Remote Sens. Environ. 2013, 128, 150-161. [CrossRef]

2. Machowski, R.; Rzetala, M.A.; Rzetala, M.; Solarski, M. Geomorphological and Hydrological Effects of Subsidence and Land use Change in Industrial and Urban Areas. Land Degrad. Dev. 2016, 27, 1740-1752. [CrossRef]

3. Abidin, H.Z.; Andreas, H.; Gumilar, I.; Fukuda, Y.; Pohan, Y.E.; Deguchi, T. Land subsidence of Jakarta (Indonesia) and its relation with urban development. Nat. Hazards 2011, 59, 1753-1771. [CrossRef]

4. Takagi, H.; Esteban, M.; Mikami, T.; Fujii, D. Projection of coastal floods in 2050 Jakarta. Urban Clim. 2016, 17, 135-145. [CrossRef]

5. Budiyono, Y.; Aerts, J.C.J.H.; Tollenaar, D.; Ward, P.J. River flood risk in Jakarta under scenarios of future change. Nat. Hazards Earth Syst. Sci. 2016, 16, 757-774. [CrossRef]

6. Abidin, H.Z.; Andreas, H.; Djaja, R.; Darmawan, D.; Gamal, M. Land subsidence characteristics of Jakarta between 1997 and 2005, as estimated using GPS surveys. GPS Solut. 2008, 12, 23-32. [CrossRef]

7. Abidin, H.Z.; Djaja, R.; Darmawan, D.; Hadi, S.; Akbar, A.; Rajiyowiryono, H.; Sudibyo, Y.; Meilano, I.; Kasuma, M.A.; Kahar, J.; et al. Land subsidence of Jakarta (Indonesia) and its geodetic monitoring system. Nat. Hazards 2001, 23, 365-387. [CrossRef]

8. Notti, D.; Mateos, R.M.; Monserrat, O.; Devanthéry, N.; Peinado, T.; Roldán, F.J.; Fernández-Chacón, F.; Galve, J.P.; Lamas, F.; Azañón, J.M. Lithological control of land subsidence induced by groundwater withdrawal in new urban AREAS (Granada Basin, SE Spain). Multiband DInSAR monitoring. Hydrol. Process. 2016, 30, 2317-2331. [CrossRef]

9. Yastika, P.E.; Shimizu, N.; Abidin, H.Z. Monitoring of long-term land subsidence from 2003 to 2017 in coastal area of Semarang, Indonesia by SBAS DInSAR analyses using Envisat-ASAR, ALOS-PALSAR, and Sentinel-1A SAR data. Adv. Space Res. 2019, 63, 1719-1736. [CrossRef]

10. Fiaschi, S.; Tessitore, S.; Bonì, R.; Di Martire, D.; Achilli, V.; Borgstrom, S.; Ibrahim, A.; Floris, M.; Meisina, C.; Ramondini, M.; et al. From ERS-1/2 to Sentinel-1: Two decades of subsidence monitored through A-DInSAR techniques in the Ravenna area (Italy). GIScience Remote Sens. 2017, 54, 305-328. [CrossRef]

11. Pradhan, B.; Abokharima, M.H.; Jebur, M.N.; Tehrany, M.S. Land subsidence susceptibility mapping at Kinta Valley (Malaysia) using the evidential belief function model in GIS. Nat. Hazards 2014, 73, 1019-1042. [CrossRef]

12. Bianchini, S.; Solari, L.; Del Soldato, M.; Raspini, F.; Montalti, R.; Ciampalini, A.; Casagli, N. Ground Subsidence Susceptibility (GSS) mapping in Grosseto plain (Tuscany, Italy) based on satellite InSAR data using frequency ratio and fuzzy logic. Remote Sens. 2019, 11, 2015. [CrossRef]

13. Arabameri, A.; Saha, S.; Roy, J.; Tiefenbacher, J.P.; Cerda, A.; Biggs, T.; Pradhan, B.; Thi Ngo, P.T.; Collins, A.L. A novel ensemble computational intelligence approach for the spatial prediction of land subsidence susceptibility. Sci. Total Environ. 2020, 726, 138595. [CrossRef]

14. Abdollahi, S.; Pourghasemi, H.R.; Ghanbarian, G.A.; Safaeian, R. Prioritization of effective factors in the occurrence of land subsidence and its susceptibility mapping using an SVM model and their different kernel functions. Bull. Eng. Geol. Environ. 2019, 78, 4017-4034. [CrossRef]

15. Oh, H.J.; Lee, S. Integration of ground subsidence hazard maps of abandoned coal mines in Samcheok, Korea. Int. J. Coal Geol. 2011, 86, 58-72. [CrossRef]

16. Oh, H.J.; Lee, S. Assessment of ground subsidence using GIS and the weights-of-evidence model. Eng. Geol. 2010, 115, 36-48. [CrossRef]

17. Pradhan, B.; Oh, H.-J.; Buchroithner, M. Weights-of-evidence model applied to landslide susceptibility mapping in a tropical hilly area. Geomat. Nat. Hazards Risk 2010, 1, 199-223. [CrossRef]

18. Kim, K.D.; Lee, S.; Oh, H.J.; Choi, J.K.; Won, J.S. Assessment of ground subsidence hazard near an abandoned underground coal mine using GIS. Environ. Geol. 2006, 50, 1183-1191. [CrossRef]

19. Hu, B.; Zhou, J.; Wang, J.; Chen, Z.; Wang, D.; Xu, S. Risk assessment of land subsidence at Tianjin coastal area in China. Environ. Earth Sci. 2009, 59, 269-276. [CrossRef]

20. Zhi-xiang, T.; Pei-xian, L.; Li-li, Y.; Ka-zhong, D. Study of the method to calculate subsidence coefficient based on SVM. Procedia Earth Planet. Sci. 2009, 1, 970-976. [CrossRef] 
21. Rahmati, O.; Falah, F.; Naghibi, S.A.; Biggs, T.; Soltani, M.; Deo, R.C.; Cerdà, A.; Mohammadi, F.; Tien Bui, D. Land subsidence modelling using tree-based machine learning algorithms. Sci. Total Environ. 2019, 672, 239-252. [CrossRef]

22. Tien Bui, D.; Shahabi, H.; Shirzadi, A.; Chapi, K.; Pradhan, B.; Chen, W.; Khosravi, K.; Panahi, M.; Bin Ahmad, B.; Saro, L. Land Subsidence Susceptibility Mapping in South Korea Using Machine Learning Algorithms. Sensors 2018, 18, 2464. [CrossRef] [PubMed]

23. Choi, J.K.; Kim, K.D.; Lee, S.; Won, J.S. Application of a fuzzy operator to susceptibility estimations of coal mine subsidence in Taebaek City, Korea. Environ. Earth Sci. 2010, 59, 1009-1022. [CrossRef]

24. Jaafari, A.; Panahi, M.; Pham, B.T.; Shahabi, H.; Bui, D.T.; Rezaie, F.; Lee, S. Meta optimization of an adaptive neuro-fuzzy inference system with grey wolf optimizer and biogeography-based optimization algorithms for spatial prediction of landslide susceptibility. Catena 2019, 175, 430-445. [CrossRef]

25. Park, I.; Choi, J.; Jin Lee, M.; Lee, S. Application of an adaptive neuro-fuzzy inference system to ground subsidence hazard mapping. Comput. Geosci. 2012, 48, 228-238. [CrossRef]

26. Lee, S.; Park, I.; Choi, J.K. Spatial prediction of ground subsidence susceptibility using an artificial neural network. Environ. Manag. 2012, 49, 347-358. [CrossRef]

27. Ambrožič, T.; Turk, G. Prediction of subsidence due to underground mining by artificial neural networks. Comput. Geosci. 2003, 29, 627-637. [CrossRef]

28. Oh, H.-J.; Syifa, M.; Lee, C.-W.; Lee, S. Land Subsidence Susceptibility Mapping Using Bayesian, Functional, and Meta-Ensemble Machine Learning Models. Appl. Sci. 2019, 9, 1248. [CrossRef]

29. Ferretti, A.; Prati, C.; Rocca, F. Permanent scatterers in SAR interferometry. IEEE Trans. Geosci. Remote Sens. 2001, 39, 8-20. [CrossRef]

30. Ferretti, A.; Savio, G.; Barzaghi, R.; Borghi, A.; Musazzi, S.; Novali, F.; Prati, C.; Rocca, F. Submillimeter accuracy of InSAR time series: Experimental validation. IEEE Trans. Geosci. Remote Sens. 2007, 45, 1142-1153. [CrossRef]

31. Hooper, A.; Bekaert, D.; Spaans, K.; Arikan, M. Recent advances in SAR interferometry time series analysis for measuring crustal deformation. Tectonophysics 2012, 514-517, 1-13. [CrossRef]

32. Hooper, A. A multi-temporal InSAR method incorporating both persistent scatterer and small baseline approaches. Geophys. Res. Lett. 2008, 35. [CrossRef]

33. Osmanoğlu, B.; Sunar, F.; Wdowinski, S.; Cabral-Cano, E. Time series analysis of InSAR data: Methods and trends. ISPRS J. Photogramm. Remote Sens. 2016, 115, 90-102. [CrossRef]

34. Osmanoǧlu, B.; Dixon, T.H.; Wdowinski, S.; Cabral-Cano, E.; Jiang, Y. Mexico City subsidence observed with persistent scatterer InSAR. Int. J. Appl. Earth Obs. Geoinf. 2011, 13, 1-12. [CrossRef]

35. Haji-Aghajany, S.; Amerian, Y. Atmospheric phase screen estimation for land subsidence evaluation by InSAR time series analysis in Kurdistan, Iran. J. Atmos. Solar Terr. Phys. 2020, 205, 105314. [CrossRef]

36. Yang, C.; Zhang, F.; Liu, R.; Hou, J.; Zhang, Q.; Zhao, C. Ground deformation and fissure activity of the Yuncheng Basin (China) revealed by multiband time series InSAR. Adv. Space Res. 2020, 66. [CrossRef]

37. Tosi, L.; Da Lio, C.; Teatini, P.; Strozzi, T. Land subsidence in coastal environments: Knowledge advance in the Venice coastland by TerraSAR-X PSI. Remote Sens. 2018, 10, 1191. [CrossRef]

38. Kim, S.W.; Dixon, T.; Amelung, F.; Wdowinski, S. A time-series deformation analysis from TerraSAR-X SAR data over New Orleans, USA. In Proceedings of the 2011 3rd International Asia-Pacific Conference on Synthetic Aperture Radar, APSAR 2011, Seoul, Korea, 26-30 September 2011; pp. 832-833.

39. Zhao, Q.; Ma, G.; Wang, Q.; Yang, T.; Liu, M.; Gao, W.; Falabella, F.; Mastro, P.; Pepe, A. Generation of long-term InSAR ground displacement time-series through a novel multi-sensor data merging technique: The case study of the Shanghai coastal area. ISPRS J. Photogramm. Remote Sens. 2019, 154, 10-27. [CrossRef]

40. Imakiire, T.; Koarai, M. Wide-area land subsidence caused by "the 2011 off the Pacific Coast of Tohoku Earthquake". Soils Found. 2012, 52, 842-855. [CrossRef]

41. Hong, S.-J.; Baek, W.-K.; Jung, H.-S. Mapping Precise Two-dimensional Surface Deformation on Kilauea Volcano, Hawaii using ALOS2 PALSAR2 Spotlight SAR Interferometry. Korean J. Remote Sens. 2019, 35, 1235-1249. [CrossRef]

42. Jo, M.; Osmanoglu, B.; Jung, H.-S. Detecting Surface Changes Triggered by Recent Volcanic Activities at Kîlauea, Hawai'i, by using the SAR Interferometric Technique: Preliminary Report. Korean J. Remote Sens. 2018, 34, 1545-1553. [CrossRef] 
43. Liu, P.; Li, Z.; Hoey, T.; Kincal, C.; Zhang, J.; Zeng, Q.; Muller, J.P. Using advanced inSAR time series techniques to monitor landslide movements in Badong of the Three Gorges region, China. Int. J. Appl. Earth Obs. Geoinf. 2012, 21, 253-264. [CrossRef]

44. Samsonov, S.; d'Oreye, N.; Smets, B. Ground deformation associated with post-mining activity at the French-German border revealed by novel InSAR time series method. Int. J. Appl. Earth Obs. Geoinf. 2013, 23, 142-154. [CrossRef]

45. Jung, H.C.; Kim, S.W.; Jung, H.S.; Min, K.D.; Won, J.S. Satellite observation of coal mining subsidence by persistent scatterer analysis. Eng. Geol. 2007, 92, 1-13. [CrossRef]

46. Ng, A.H.M.; Ge, L.; Li, X.; Abidin, H.Z.; Andreas, H.; Zhang, K. Mapping land subsidence in Jakarta, Indonesia using persistent scatterer interferometry (PSI) technique with ALOS PALSAR. Int. J. Appl. Earth Obs. Geoinf. 2012, 18, 232-242. [CrossRef]

47. BPS-Statistics of DKI Jakarta Province. DKI Jakarta Province in Figures; Division of Integration Processing and Statistics Dissemination BPS-Statistics of DKI Jakarta Province, Ed.; BPS-Statistics of DKI Jakarta Province: Jakarta, Indonesia, 2020; ISBN 978-602-0922-38-6.

48. Hudalah, D.; Firman, T. Beyond property: Industrial estates and post-suburban transformation in Jakarta Metropolitan Region. Cities 2012, 29, 40-48. [CrossRef]

49. Abidin, H.Z.; Andreas, H.; Gamal, M.; Gumilar, I.; Napitupulu, M.; Fukuda, Y.; Deguchi, T.; Maruyama, Y. Edi Riawan Land subsidence characteristics of the Jakarta basin (Indonesia) and its relation with groundwater extraction and sea level rise. Groundw. Response Chang. Clim. 2010, 113-130. [CrossRef]

50. Arabameri, A.; Lee, S.; Tiefenbacher, J.P.; Ngo, P.T.T. Novel Ensemble of MCDM-Artificial Intelligence Techniques for Groundwater-Potential Mapping in Arid and Semi-Arid Regions (Iran). Remote Sens. 2020, 12, 490. [CrossRef]

51. Farr, T.G.; Rosen, P.A.; Caro, E.; Crippen, R.; Duren, R.; Hensley, S.; Kobrick, M.; Paller, M.; Rodriguez, E.; Roth, L.; et al. The Shuttle Radar Topography Mission. Rev. Geophys. 2007, 45, RG2004. [CrossRef]

52. Pourghasemi, H.R.; Beheshtirad, M. Assessment of a data-driven evidential belief function model and GIS for groundwater potential mapping in the Koohrang Watershed, Iran. Geocarto Int. 2015, 30, 662-685. [CrossRef]

53. Lee, S.; Park, I. Application of decision tree model for the ground subsidence hazard mapping near abandoned underground coal mines. J. Environ. Manag. 2013, 127, 166-176. [CrossRef]

54. Hooper, A. Persistent scatter radar interferometry for crustal deformation studies and modeling of volcanic deformation. Ph.D. Thesis, Stanford University, Stanford, CA, USA, 2006.

55. Wegnüller, U.; Werner, C.; Strozzi, T.; Wiesmann, A.; Frey, O.; Santoro, M. Sentinel-1 Support in the GAMMA Software. Procedia Comput. Sci. 2016, 100, 1305-1312. [CrossRef]

56. Werner, C.; Wegmüller, U.; Strozzi, T.; Wiesmann, A. GAMMA SAR and interferometric processing software. In Proceedings of the ERS-ENVISAT Symposium, Gothenburg, Sweden, 16-20 October 2000.

57. Crosetto, M.; Monserrat, O.; Cuevas-González, M.; Devanthéry, N.; Crippa, B. Persistent Scatterer Interferometry: A review. ISPRS J. Photogramm. Remote Sens. 2016, 115, 78-89. [CrossRef]

58. Hooper, A.; Segall, P.; Zebker, H. Persistent scatterer interferometric synthetic aperture radar for crustal deformation analysis, with application to Volcán Alcedo, Galápagos. J. Geophys. Res. Solid Earth 2007, 112, 1-21. [CrossRef]

59. Sousa, J.J.; Hooper, A.J.; Hanssen, R.F.; Bastos, L.C.; Ruiz, A.M. Persistent Scatterer InSAR: A comparison of methodologies based on a model of temporal deformation vs. spatial correlation selection criteria. Remote Sens. Environ. 2011, 115, 2652-2663. [CrossRef]

60. Pepe, A.; Bonano, M.; Zhao, Q.; Yang, T.; Wang, H. The Use of C-/X-Band Time-Gapped SAR Data and Geotechnical Models for the Study of Shanghai's Ocean-Reclaimed Lands through the SBAS-DInSAR Technique. Remote Sens. 2016, 8, 911. [CrossRef]

61. Floris, M.; Fontana, A.; Tessari, G.; Mulè, M. Subsidence Zonation Through Satellite Interferometry in Coastal Plain Environments of NE Italy: A Possible Tool for Geological and Geomorphological Mapping in Urban Areas. Remote Sens. 2019, 11, 165. [CrossRef]

62. Ren, H.; Feng, X. Calculating vertical deformation using a single InSAR pair based on singular value decomposition in mining areas. Int. J. Appl. Earth Obs. Geoinf. 2020, 92, 102115. [CrossRef]

63. Freund, Y.; Schapire, R.E. A Decision-Theoretic Generalization of On-Line Learning and an Application to Boosting. J. Comput. Syst. Sci. 1997, 55, 119-139. [CrossRef] 
64. Kadavi, P.; Lee, C.-W.; Lee, S. Application of Ensemble-Based Machine Learning Models to Landslide Susceptibility Mapping. Remote Sens. 2018, 10, 1252. [CrossRef]

65. Sprenger, M.; Schemm, S.; Oechslin, R.; Jenkner, J. Nowcasting foehn wind events using the AdaBoost machine learning algorithm. Weather Forecast. 2017, 32, 1079-1099. [CrossRef]

66. Friedman, J.; Hastie, T.; Tibshirani, R. Additive logistic regression: A statistical view of boosting. Ann. Stat. 2000, 28, 337-407. [CrossRef]

67. Zhang, G.; Fang, B. LogitBoost classifier for discriminating thermophilic and mesophilic proteins. J. Biotechnol. 2007, 127, 417-424. [CrossRef]

68. Lee, S. Application of logistic regression model and its validation for landslide susceptibility mapping using GIS and remote sensing data. Int. J. Remote Sens. 2005, 26, 1477-1491. [CrossRef]

69. Erener, A.; Mutlu, A.; Sebnem Düzgün, H. A comparative study for landslide susceptibility mapping using GIS-based multi-criteria decision analysis (MCDA), logistic regression (LR) and association rule mining (ARM). Eng. Geol. 2016, 203, 45-55. [CrossRef]

70. Ozdemir, A.; Altural, T. A comparative study of frequency ratio, weights of evidence and logistic regression methods for landslide susceptibility mapping: Sultan mountains, SW Turkey. J. Asian Earth Sci. 2013, 64, 180-197. [CrossRef]

71. David, W.; Hosmer, J.; Lemeshow, S.; Sturdivant, R.X. Applied Logistic Regression, 3rd ed.; John Wiley \& Sons, Ltd.: Hoboken, NJ, USA, 2013.

72. Pham, B.T.; Tien Bui, D.; Prakash, I.; Dholakia, M.B. Hybrid integration of Multilayer Perceptron Neural Networks and machine learning ensembles for landslide susceptibility assessment at Himalayan area (India) using GIS. Catena 2017, 149, 52-63. [CrossRef]

73. Gardner, M.W.; Dorling, S.R. Artificial neural networks (the multilayer perceptron)—A review of applications in the atmospheric sciences. Atmos. Environ. 1998, 32, 2627-2636. [CrossRef]

74. Kim, S.-W.; Wdowinski, S.; Dixon, T.H.; Amelung, F.; Won, J.-S.; Kim, J.W. InSAR-based mapping of surface subsidence in Mokpo City, Korea, using JERS-1 and ENVISAT SAR data. Earth Planets Space 2008, 60, 453-461. [CrossRef]

75. Fawcett, T. An introduction to ROC analysis. Pattern Recognit. Lett. 2006, 27, 861-874. [CrossRef]

76. Van Leijen, F.J. Persistent Scatterer Interferometry based on geodetic estimation theory. Ph.D. Thesis, Technische Universiteit Delft, Delft, The Netherlands, 2014.

77. Colesanti, C.; Ferretti, A.; Novali, F.; Prati, C.; Rocca, F. SAR monitoring of progressive and seasonal ground deformation using the permanent scatterers technique. IEEE Trans. Geosci. Remote Sens. 2003, 41, 1685-1701. [CrossRef]

78. Smith, R.G.; Knight, R.; Chen, J.; Reeves, J.A.; Zebker, H.A.; Farr, T.; Liu, Z. Estimating the permanent loss of groundwater storage in the southern San Joaquin Valley, California. Water Resour. Res. 2017, 53, 2133-2148. [CrossRef]

79. Reeves, J.A.; Knight, R.; Zebker, H.A.; Kitanidis, P.K.; Schreüder, W.A. Estimating temporal changes in hydraulic head using InSAR data in the San Luis Valley, Colorado. Water Resour. Res. 2014, 50, 4459-4473. [CrossRef]

80. Erban, L.E.; Gorelick, S.M.; Zebker, H.A. Groundwater extraction, land subsidence, and sea-level rise in the Mekong Delta, Vietnam. Environ. Res. Lett. 2014, 9. [CrossRef]

81. Erban, L.E.; Gorelick, S.M.; Zebker, H.A.; Fendorf, S. Release of arsenic to deep groundwater in the Mekong Delta, Vietnam, linked to pumping-induced land subsidence. Proc. Natl. Acad. Sci. USA 2013, 110, 13751-13756. [CrossRef] [PubMed]

Publisher's Note: MDPI stays neutral with regard to jurisdictional claims in published maps and institutional affiliations.

(C) 2020 by the authors. Licensee MDPI, Basel, Switzerland. This article is an open access article distributed under the terms and conditions of the Creative Commons Attribution (CC BY) license (http://creativecommons.org/licenses/by/4.0/). 